\title{
Bilgi Ekonomisi Göstergeleri Bakımından Türkiye'nin Avrupa ve Orta Asya Ülkeleri Arasındaki Yeri
}

The Position of Turkey among European and Central Asian Countries with regards to Knowledge Economy Indicators

\section{Sultan Salur ${ }^{1}$}

Başvuru Tarihi: 08.09.2018

Kabul Tarihi: 13.09.2019

Öz

Son yıllarda dünya ekonomilerinde bilgi ekonomisinin öneminin arttı̆̆ı görülmektedir. Bu ekonominin temelini yeni teknolojiler, bu teknolojilerin geliștirilmesi ve yayılması oluşturmaktadır. Bilgi ekonomisi, gelişmiş ülkelerin yakalamış olduğu bir seviye olarak kabul görmektedir. Bu seviyeyi yakalamayı hedefleyen gelişmekte olan ülkelerde teknolojik yatırımlara ve beşeri sermayeye gereken önem verilmelidir.

Bilgi ekonomisi bakımından ülkelerin performansları çeşitli değişkenler tarafından incelenmektedir. Bu çalışmada, Dünya Bankası'nın geliştirdiği KAM Metodolojisinin (The Knowledge Assessment Methodology) gruplandırmış olduğu Avrupa ve Orta Asya'da yer alan 26 ülke ve yine bu yöntemin belirlediği değişkenlerden ulaşılabilir olanlarla bir karşılaştırma yapılmıştır. Yapılan karşılaştırmalar Türkiye’nin içinde bulunduğu grupta orta seviyede performans gösterdiğini ortaya koymaktadır.

Anahtar Kelimeler: Bilgi Ekonomisi, Bilgi ve İletişim Teknolojileri, Araştırma ve Geliştirme

\begin{abstract}
In recent years it has been seen that the importance of knowledge economy has increased in world economies. This economy is based on the emerging technologies, development and spread of these technologies. Knowledge economy is assumed as a kind of level that developed countries have achieved to reach. Developing countries intending to reach this level should attach importance to technological investments and human capital.

Various variables are used to evaluate the countries' performances in information economy. In this study, 26 countries in Europe and Central Asia grouped by the World Bank-developed KAM methodology (The Knowledge Assessment Methodology) and those available variables determined by this method are compared. The comparison indicates that Turkey has ranked in the mid-range within its own group.
\end{abstract}

Keywords: Knowledge Economy, Information and communication Technology, Research and Development

\footnotetext{
${ }^{1}$ Sinop Üniversitesi, Boyabat İİBF, ssalur@sinop.edu.tr, ORCID: 0000-0001-9314-3526
} 


\section{Giriş}

Dünya ekonomilerinde sanayi ekonomisinden bilgi ekonomisine doğru hızlı bir dönüşümün yaşandığı görülmektedir. Yeni teknolojilerin geliştirilmesi ve bu teknolojilerin diğer ülkelere yayılması bu dönüşümün temelini oluşturmaktadır. Bilginin, ekonomik alanda öneminin artmasıyla birlikte bilgi ekonomisi ön plana çıkmıştır.

20. yüzyılın ikinci yarısından itibaren sanayi ekonomisiyle birlikte yeni bir ekonomik sistem olan bilgi ekonomisinin etkileri de gözlenmeye başlamıştır. Teknolojik ilerlemeler, ülkelerin rekabet gücünün ve ekonomik büyümenin artmasını sağlayan temel unsur haline gelmiştir (Salur vd., 2016, s. 2098).

Bilgi ekonomisi son yıllarda çokça konuşulan kavramlardan birisi olup, farklı şekillerde tanımlanmaktadır. Küresel rekabet çağındaki klasik ekonomi kuramlarının geçersiz oluşu, teknolojik alanda yaşanan hızlı değişimler, üretim ve verimlilik artışında bilişim ve iletişim teknolojilerinin etkisinin anlaşılması gibi faktörler tanımların farklı şekillerde yapılmasına neden olmaktadır (Özsağır, 2007, s. 30).

Avrupa'da genel olarak bilgi ekonomisi, elektronik enformasyon teknolojilerinin yaratılması ve uygulanmasının merkezinde yer alan ekonomik faaliyet endüstrisi olarak tanımlanmaktadır (Zagler, 2002, s. 338). Bilgi ekonomisi, enformasyon ve iletişim teknolojilerinde gerçekleşen gelişmeleri ve bu gelişmelerin ekonomik, sosyal, kültürel ve siyasal hayata olan etkilerini açıklamak amacıyla kullanılan ve dünya geneline hızla yayılan bir kavramdır. İnternetin yaygın bir şekilde kullanılması, elektronik ticaretin ön plana geçmesi ve çalışma yapısındaki değişiklikler ve buna bağlı olarak yeni isletme kültürünün oluşması gibi çeşitli etkenler bilgi ekonomisinde değerlendirilmektedir.

Bilgi ekonomisine dar ve geniş olarak ifade edilmek istenirse;

- Geniş Anlamda Bilgi Ekonomisi

Stiroh (2001a: 2) bilgi ekonomisini, 1990’lı yılların sonlarında yaşanan, verimlilik artışı, issizlik oranlarının azalışı ve enflasyon arasındaki ilişki şeklinde tanımlamıştır. Yazar ekonomik faaliyetlerde teknolojinin, küreselleşmenin ve artan rekabetin etkili olduğunu ifade etmiştir. Davies v.d. (2000:3) bilgi ekonomisini, son yllarda ABD ekonomisinin performansında meydana gelen artışın ifade ettiği "yeni bir paradigma" olarak tanımlamışlardır. Yazarlara göre teknolojik ilerleme, küreselleşme, işgücü ve üretim piyasasında meydana gelen yapısal değişiklikler bu yeni paradigmanın belirleyicisi olmuştur. Fraumeni ve Landefeld (2001: 23) çalışmalarında bilgi ekonomisini küreselleşme, artan uluslararası rekabet ve en önemlisi teknolojik gelişmeler gibi çeşitli faktörlerin ortaya çıkardığını belirtmektedirler. Atkinson ve Court (1998a)' a göre bilgi ekonomisi, bilgi ve düşünce temelli bir ekonomi olup, yenilikçi fikirlerin ve teknolojinin ekonomideki önemine işaret etmektedirler.

- Dar Anlamda Bilgi Ekonomisi

Gordon (2000: 2)' a göre bilgi ekonomisini, 1990'ların ortalarında bilgisayar donanımı, yazılımı ve telefon hizmetlerinin fiyatlarında görülen hızlı düşüş ile telekomünikasyon 
kapasitesinin artışı ve bilgisayar işlem gücünün hızlanmasıyla internetin çok hızlı bir şekilde yayılmasını ifade etmektedir. Nordhaus (2000: 2) bilgi ekonomisini makineleşme, elektrik aletleri, telefon, telgraf ve yazılım sektörlerindeki gelişmeler şeklinde tanımlamıştır. Bosworth ve Triplett (2001: 2-4), bilgi ekonomisini, bilgi ve iletişim teknolojileriyle ilişkilendirmişler ve bilgi ve iletişim teknolojilerinin en önemli etkisinin ise çıtı ve verimlilik artısına neden olduğunu iddia etmişlerdir. Salvatore’a (2003: 534) göre bilgi ekonomisi; bilgisayar, yazılım ve komünikasyona dayanan bir ekonomi olup, bilgi ve iletisim teknolojilerinin kullanımının hızla yayılmasıdır.

Genel olarak ifade edilmek istenirse bilgi ekonomisi, bilginin ekonomik ve insani kalkınma için etkili bir biçimde kullanıldığı bir ekonomik yapıdır (Özsağır,2007: 30). Buna göre bilgi ve iletişim temelli bilgi ekonomisinin temel özellikleri (Akın, 2009; Uğur ve Sahin, 2009):

- Sürekli hızlanan teknolojideki gelişmeler,

- Bilişim ve bilgi yoğun faaliyetlerdeki artış,

- Pazara girme ve ürün/hizmet hayat dönüşüm sürelerinin kısalması,

- Piyasaların küreselleşmesi,

- Sanayi kolları arasındaki farkların belirsizleşmesi, şeklinde sıralanabilmektedir.

1980'li yıllarda Amerika Birleşik Devletleri’nde, bilgi teknolojilerine yapılan yatırımlar, 1990'lı yllarda beklenilenin üzerinde büyümeye ve istihdam artışına neden olmuştur. Bazı ülkelerin diğer ülkelere göre neden daha hızlı büyüme kaydettiklerinin araştırılmasında verimlilik artışı dikkat çekmiştir. Verimlilik artışının temelinde ise bilgi ve iletişim teknolojilerine yapılan yatırımların önemi anlaşılmışıı (Özsağır, 2007, s. 30).

Bilgi ve iletişim teknolojilerindeki (BİT) yenilikler, küreselleşmenin gelişmesini tetikleyerek sosyal ve ekonomik hayatın çeşitli şekillerde etkilenmesine neden olmuştur. Aynı zamanda bilgi ekonomisinin öneminin artmasılyla birlikte istihdam yapısında da değişmeler gözlenmektedir. İstihdam yapısı değerlendirildiğinde sanayi sektörünü temsil eden mavi yakalı işçilerin yerini bilgi ekonomisinde hizmet sektörünü temsil eden beyaz yakalı işçiler almıştır. Bununla birlikte nitelikli işgücünün önemi daha çok anlaşılır hale gelmiştir.

Bilgi ekonomisi, gelişmiş ülkelerin yakalamış olduğu bir düzey olarak kabul edilmektedir. Bu sebeple gelişmekte olan ülkelerin bu düzeyi yakalayabilmeleri için sanayileşme politikalarını gözden geçirerek teknolojik yatırımlara gereken önemi vermeleri zorunluluk haline gelmiştir. $\mathrm{Bu}$ çalışmanın amacı KAM 'ın yapmış olduğu gruplardan Türkiye'nin de içine bulunduğu Avrupa ve Orta Asya grubunun bilgi ekonomisi performanslarını betimleyici bir şekilde özellikle son yılları değerlendiren bir karşılaştırma yapmaktır. Sonuç itibariyle ortaya konulan şey Türkiye'nin bilgi ekonomisi performansı grupta yer alan diğer ülkelere göre orta düzeyde olduğudur. Ülkelerin performansları yine bu metodolojinin belirlemiş olduğu "Performans Göstergeleri”, "Ekonomik Rejim", "Kurumlar", "Eğitim ve İnsan Kaynakları", "İnovasyon Sistemi" ve "Bilgi Altyapısı" başlıklarında yer alan değişkenlerce incelenmektedir.

KAM, Dünya Bankasının "Kalkınma İçin Bilgi" programı tarafından geliştirilen bir yöntem olup, ülkelerin bilgi ekonomisine yönelik performanslarını analiz etmelerine olanak 
sağlamaktadır. Bu metodoloji, ülkelere kendilerini komşularıyla, rakipleriyle ve diğer ülkelerle bilgi ekonomisi konusunda hem zayıf hem de güçlü yönlerini karşılaştırmalarına olanak sağlamaktadır (Chen ve Dahlman, 2005: 9). KAM yöntemi, ülkelerin kendi avantaj ve dezavantajlarını ortaya koyarak, ülkelerin bilgi ekonomisinde istedikleri seviyeye çıkabilmeleri için yapmaları gereken durumlar için yol gösterici rol oynamaktadır (Salur, 2016, s. 168).

\section{Literatür Taraması}

Bilgi ekonomisinde ülkelerin performansları literatürde ampirik ve ülkeler arasında betimsel karşılaştırmalar yapılarak incelenmiştir. Bu çalışmalardan bazıları şunlardır:

Barışık ve Yirmibeşcik (2006), çalışmalarında Türkiye'de yeni ekonomin avantajlarından yeterince yararlanılamadığı ve yeni ekonominin oluşum sürecini hızlandıracak çalışımların gerektiği sonucuna ulaşmışlardır.

Ersöz (2009), çalışmasında Türkiye'nin inovasyon açısından gelişmiş ülkelerle karşılaştırıldığında hangi konumda olduğunu ortaya koymak amaçlanmıştır. Yapılan analizler Türkiye'nin inovasyon göstergelerindeki Hiyerarşik Kümeleme Analizine göre; Çek Cumhuriyeti, Estonya, İspanya, Letonya, Litvanya, Macaristan, Malta, Polonya, Portekiz, Slovakya, Slovenya ve Yunanistan ile aynı kümede yer aldığını ortaya koymaktadır. Çok Boyutlu Ölçekleme Analizi sonucuna göre ise, Türkiye inovasyon göstergeleri bakımından ABD, AB ülkeleri, Japonya ve İsrail içinde düşük ülke özelliği gösterdiği sonucuna ulaşılmıştır.

Erkekoğlu ve Arıç (2013), çalışmalarında Bilgi Ekonomisi İndeksi, Bilgi İndeksi, Ekonomik Teşvik ve Kurumsal Rejim, İnovasyon Sistemi, Eğitim ve Beşeri Kaynaklar, Bilgi ve İletişim Teknolojileri değişkenlerini kullanmışlardır. Çalışmada 20 APEC ülkesi ve Türkiye yer almaktadır ve çalışmanın yöntemi hiyerarşik kümeleme analizidir. Türkiye’nin 2012 yılında dünyada bilgi toplumu göstergeleri indeksi sıralamasında 69. sırada yer aldığı görülmektedir. Meçik (2013), çalışmasında Türkiye’nin bilgi ekonomisindeki konumunu 2010-2012 döneminde Bilgi Değerlendirme Metodolojisi ile analiz yapmıştır. Çalışma sonucu Türkiye’nin bilgi ekonomisinde önemli hamleler yapmasına rağmen bu hamlelerin yetersiz olduğunu göstermektedir.

Seyfullahoğulları ve Akbaş (2013), çalışmalarında gelişmiş ve gelişmekte olan on dokuz ülkede çeşitli sosyal ve bilgi iletişim teknolojileri arasındaki ilişki ve bilgi iletişim teknolojilerinin ülkelerin büyümesindeki etkileri faktör analizi ve çok boyutlu ölçekleme yöntemleri ile incelemişlerdir. Bilgi iletişim teknolojilerindeki özellikler açısından birbirine en çok benzerlik gösteren ülkeler, Almanya, Belçika, Fransa, Hollanda ve İsveç'tir. Boyutlara göre Ülkelerin Haritası incelendiğinde ideal konuma en uzak olan ülkeler ise Türkiye ve Bulgaristan'dır.

Türedi (2013), çalışmasında bilgi ve iletişim teknolojilerinin ekonomik büyümedeki etkisini Türkiye'nin de yer aldığ 30 gelişmekte olan ve 23 gelişmiş toplam 53 ülkede 1995-2008 dönemini kapsayacak şekilde panel veri yöntemi ile tahmin etmiştir. Araştırma sonuçlarına göre bilgi ve iletişim teknolojilerinin büyüme üzerindeki etkisi gelişmiş ülkelerde daha fazla 
olmakla birlikte bilgi ve iletişim teknolojileri gelişmiş ve de gelişmekte olan ülkelerde ekonomik büyümeye pozitif etki yapmaktadır.

Ünal ve Seçilmiş (2013), Türkiye'nin Ar-Ge faaliyetleri bakımında dünyadaki gelişmiş ekonomilere göre konumunu belirmeyi amaçladıkları çalışmalarında, Türkiye'nin gelişmiş ülkeleri geriden takip ettiği sonucuna ulaşmışlardır.

Şanlısoy (2015), çalışmasında Türk Cumhuriyetleri'nde bilgi ekonomisi performansları analiz ederek bu ülkelerin bilgi ekonomisi olma sürecinin neresinde olduğunu incelemiştir. Buradan hareketle bilgi, bilgi ekonomisi ve ağa hazırlık endeksleri ile analiz yapılmıştır. İlgili ülkelerin bilgi ekonomisine dönüşümünde uzun uğraşılar gerektiği sonucuna ulaşmıştır.

Ersöz vd. (2016), çalışmalarında Türkiye'nin Avrupa'da ve Dünya ülkeleri içinde inovasyondaki konumunu belirlemeye çalışmışlardır bunun için inovasyon göstergelerinde çok değişkenli istatistik teknikler kullanmışlardır. Araştırma sonucu Türkiye'nin Akdeniz ve Doğu Avrupa ülkeleri ile aynı grupta yer aldığını göstermektedir.

Salur vd. (2016), çalışmalarında bilgi toplumunun ekonomik parametrelerinin Türkiye'de ve AB Ülkelerinin bilgi ekonomisine ne kadar uyum sağladığını tespit etmeye çalışmışlardır. Bunun için internet kullanıcıları, GSYİH' nın yüzdesi olarak toplam Ar-Ge harcamaları, cep telefonu abonelikleri, Ar-Ge araştırmacılarının sayısı, BİT ürünleri ihracatı, orta öğretime katılma oranı ve yükseköğretime katılma oranı değişkenlerini 2000-2013 döneminde Türkiye'de ve AB ülkelerinde için karşılaştırmışlardır. Yapılan karşılaş̧ırmalar Türkiye'nin AB ülkelerini çok geriden takip ettiği açık bir şekilde göstermektedir.

Sayar - Özkan ve Erdal Alancioğlu (2017), çalışmalarında Türkiye'deki bilgi ekonomisi dönüşümünü Bilgi Ekonomisi İndeksi ile birlikte Ar-Ge harcamaları, bilimsel yayın, bilim ve teknolojide yer alan insan kaynağı ve patent değişkenleri analiz etmişlerdir. Araştırma bulgularına göre Ar-Ge harcamaları ile ile patent sayıları arasında çift yönlü ilişki tespit edilmiştir.

Gelgeç ve Hatırlı (2018), çalışmalarında Türkiye'deki bilgi ekonomisi ile ekonomik büyüme arasındaki ilişkinin analizi etmişlerdir. Sabit fiyatlarla gayri safi yurtiçi hasıla, Ar-Ge insan gücü, yüksek öğretimdeki öğrenci sayısı ve ileri teknoloji ihracatı bağımsız değişkenlerini kullanmışlardır. Tahmin sonuçları bilgi ekonomisi ile büyüme arasında uzun dönemde; yükseköğretimdeki Ar-Ge insan gücü anlamlı değilken, ileri teknoloji ihracatı ve yükseköğretimdeki öğrenci sayısı da GSYH'yı negatif yönden etkilemiş ve katsayılar istatistiki olarak anlamlı olduğunu göstermektedir.

Odabaşı ve Erdal (2018), çalışmalarında ele aldıkları seçilmiş OECD ülkelerinde büyüme rakamları ile yüksek AR-GE harcaması, patent sayısı, araştırmacı sayısı ve bilimsel yayın sayıları arasında doğru yönlü bir ilişki olduğunu ifade etmektedirler. Türkiye’nin henüz bu anlamda yarı sanayileşmiş ülke konumunda olduğunu belirtmektedirler. 


\section{Bilgi Ekonomisi Performans Göstergeleri}

Araştırmada bilgi ekonomisi performansları karşılaştırılırken GSYİH, İnsani Gelişim İndeksi, Sanayi Sektöründeki İstihdam Oranı, Hizmetler Sektöründeki İstihdam Oranı, Mal ve Hizmet İhracat1, Ticaret özgürlüğü, Hükümet Etkinliği, Düzenleme Niteliği, Hukuk Kuralı, Doğumda Yaşam Beklentisi, Ortaöğretime Katılma Oranı, Yükseköğretime Katılma Oranı, Yüksek Teknoloji İhracatı, Patent Sayısı, Ar-ge Harcamaları, Ar-Ge Araştırmacıları, Bilimsel ve Teknik Makaleleri, Telefon Aboneliği ve İnternet Kullanıcıları değişkenleri kullanılmıştır. Çalışmada ülkelerin 2006-2016 döneminde almış oldukları veriler Dünya Banka’sından temin edilmiştir. Dünya Bankası'nın geliştirmiş olduğu KAM Metodolojisinin gruplandırmış olduğu Türkiye'nin içinde yer aldığı Avrupa ve Orta Asya'da yer alan 26 ülke incelenmiştir. Bu çalışmadaki amaç ilgili dönemde ülkelerin bilgi ekonomisi performans göstergelerinin almış oldukları değerleri karşılaştırarak, Türkiye'nin grupta yer alan diğer ülkeler karşısında bilgi ekonomisindeki konumunu ortaya koymaktır.

\section{Performans Göstergeleri}

\section{GSYiH}

Tablo 1. GSYİH Büyüme (\%), (2006-2016)

\begin{tabular}{|c|c|c|c|c|c|c|c|c|c|c|c|}
\hline Ülkeler & 2006 & 2007 & 2008 & 2009 & 2010 & 2011 & 2012 & 2013 & 2014 & 2015 & 2016 \\
\hline Arnavutluk & 5,4 & 5,9 & 3,8 & 3,4 & 3,7 & 2,6 & 1,4 & 1,0 & 1,8 & 2,2 & 3,4 \\
\hline Ermenistan & 13,2 & 13,7 & 6,9 & $-14,1$ & 2,2 & 4,7 & 7,2 & 3,3 & 3,6 & 3,2 & 0,2 \\
\hline Bulgaristan & 6,9 & 7,3 & 6,0 & $-3,6$ & 1,3 & 1,9 & 0,0 & 0,9 & 1,3 & 3,6 & 3,9 \\
\hline Bosna Hersek & 5,4 & 5,7 & 5,6 & $-3,0$ & 0,9 & 1,0 & $-0,8$ & 2,3 & 1,1 & 3,1 & 3,1 \\
\hline Belarus & 10,0 & 8,6 & 10,2 & 0,2 & 7,8 & 5,5 & 1,7 & 1,0 & 1,7 & $-3,8$ & $-2,5$ \\
\hline Çek Cumh. & 6,9 & 5,6 & 2,7 & $-4,8$ & 2,3 & 1,8 & $-0,8$ & $-0,5$ & 2,7 & 5,3 & 2,6 \\
\hline Estonya & 10,3 & 7,7 & $-5,4$ & $-14,7$ & 2,3 & 7,6 & 4,3 & 1,9 & 2,9 & 1,7 & 2,1 \\
\hline Gürcistan & 9,4 & 12,3 & 2,3 & $-3,7$ & 6,2 & 7,2 & 6,4 & 3,4 & 4,6 & 2,9 & 2,8 \\
\hline Hirvatistan & 4,8 & 5,2 & 2,1 & $-7,4$ & $-1,4$ & $-0,3$ & $-2,2$ & $-0,6$ & $-0,1$ & 2,3 & 3,2 \\
\hline Macaristan & 3,9 & 0,4 & 0,9 & $-6,6$ & 0,7 & 1,7 & $-1,6$ & 2,1 & 4,2 & 3,4 & 2,2 \\
\hline Kazakistan & 10,7 & 8,9 & 3,3 & 1,2 & 7,3 & 7,4 & 4,8 & 6,0 & 4,2 & 1,2 & 1,1 \\
\hline Kırgızistan & 3,1 & 8,5 & 8,4 & 2,9 & $-0,5$ & 6,0 & $-0,1$ & 10,9 & 4,0 & 3,9 & 4,3 \\
\hline Litvanya & 7,4 & 11,1 & 2,6 & $-14,8$ & 1,6 & 6,0 & 3,8 & 3,5 & 3,5 & 2,0 & 2,3 \\
\hline Letonya & 11,9 & 10,0 & $-3,5$ & $-14,4$ & $-3,9$ & 6,4 & 4,0 & 2,4 & 1,9 & 3,0 & 2,2 \\
\hline Moldova & 4,8 & 3,0 & 7,8 & $-6,0$ & 7,1 & 6,8 & $-0,7$ & 9,4 & 4,8 & $-0,4$ & 4,5 \\
\hline Karadağ & 8,6 & 6,8 & 7,2 & $-5,8$ & 2,7 & 3,2 & $-2,7$ & 3,5 & 1,8 & 3,4 & 2,9 \\
\hline Polonya & 6,2 & 7,0 & 4,2 & 2,8 & 3,6 & 5,0 & 1,6 & 1,4 & 3,3 & 3,8 & 2,9 \\
\hline Romanya & 8,1 & 6,9 & 8,3 & $-5,9$ & $-2,8$ & 2,0 & 1,2 & 3,5 & 3,1 & 4,0 & 4,8 \\
\hline Rusya & 8,2 & 8,5 & 5,2 & $-7,8$ & 4,5 & 5,3 & 3,7 & 1,8 & 0,7 & $-2,8$ & $-0,2$ \\
\hline Surbistan & 4,9 & 5,9 & 5,4 & $-3,1$ & 0,6 & 1,4 & $-1,0$ & 2,6 & $-1,8$ & 0,8 & 2,8 \\
\hline Slovakya & 8,5 & 10,8 & 5,6 & $-5,4$ & 5,0 & 2,8 & 1,7 & 1,5 & 2,8 & 3,9 & 3,3 \\
\hline Slovenya & 5,7 & 6,9 & 3,3 & $-7,8$ & 1,2 & 0,6 & $-2,7$ & $-1,1$ & 3,0 & 2,3 & 3,1 \\
\hline Tacikistan & 7,0 & 7,8 & 7,9 & 3,8 & 6,5 & 7,4 & 7,5 & 7,4 & 6,7 & 6,0 & 6,9 \\
\hline Türkiye & 7,1 & 5,0 & 0,8 & $-4,7$ & 8,5 & 11,1 & 4,8 & 8,5 & 5,2 & 6,1 & 3,2 \\
\hline Ukrayna & 7,3 & 7,9 & 2,3 & $-14,8$ & 4,2 & 5,5 & 0,2 & 0,0 & $-6,6$ & $-9,8$ & 2,3 \\
\hline Özbekistan & 7,3 & 9,9 & 9,0 & 8,1 & 8,5 & 8,3 & 8,2 & 8,0 & 7,8 & 8,0 & 7,8 \\
\hline
\end{tabular}

Tablo 1'de ülkelerin 2006-2016 dönemine ait GSYİH rakamlarındaki büyümeye ilişkin veriler yer almaktadır. Rakamlar incelendiğinde ülkelerin çoğunda GSYİH değerlerin azaldığı görülmektedir. 2016 yılı itibariyle en büyük büyüme \%7,8 ile Özbekistan'da gerçekleşmiş, bu ülkeyi \%6.9 ile Tacikistan, \%4.8 ile de Romanya takip etmiştir. Tabloda dikkat çeken bir diğer 
durum ise - \%2,5 ile Belarus ve - \% 0,2 ile Rusya'da negatif büyümenin gerçekleşmiş olmasıdır. Tablo incelendiğinde 2016 yılında gerçekleşen ekonomik büyüme Kırgızistan ve Özbekistan’da artarken diğer ülkelerde azalmaktadır.

\section{Insani Gelişim Endeksi}

İnsani gelişim endeks değerlerinin yer aldığı aşağıdaki tabloda 1990-2015 döneminde endeks değerlerinin 0,7 ile 0,9 arasında değiştiği görülmemektedir (Bkz. Tablo 2). Slovenya, Çek Cumhuriyeti, Estonya, Polonya 0,9'luk en yüksek endeks değerine sahip iken Tacikistan'ın 0,6'lık endeks değeriyle en son sırada yer aldığı görülmektedir. 2015 yılı itibariyle Türkiye'nin insani gelişim endeksi 0,8'dir. 1990-2015 dönemi genel olarak değerlendirildiğinde Tacikistan haricindeki diğer ülkelerin tamamında endeks değerinin arttığ 1 , Tacikistan'da ise 2015 yılındaki endeks değerinin 1990 yılındaki endeks değerine göre değişmediği görülmektedir. Tabloda yer alan diğer ülkeler ile karşılaştırıldığında Türkiye insani gelişim endeksine göre 0,8 değerini alan on beş ülke ile ikinci sırada yer almaktadır.

Tablo 2. İnsani Gelişim Endeksi Ĕ̆ilimleri (1990-2015)

\begin{tabular}{|c|c|c|c|c|c|c|c|c|}
\hline Ülkeler & 1990 & 2000 & 2010 & 2011 & 2012 & 2013 & 2014 & 2015 \\
\hline Slovenya & 0,8 & 0,8 & 0,9 & 0,9 & 0,9 & 0,9 & 0,9 & 0,9 \\
\hline Çek Cum. & 0,8 & 0,8 & 0,9 & 0,9 & 0,9 & 0,9 & 0,9 & 0,9 \\
\hline Estonya & 0,7 & 0,8 & 0,8 & 0,8 & 0,9 & 0,9 & 0,9 & 0,9 \\
\hline Polonya & 0,7 & 0,8 & 0,8 & 0,8 & 0,8 & 0,8 & 0,9 & 0,9 \\
\hline Litvanya & 0,7 & 0,8 & 0,8 & 0,8 & 0,8 & 0,8 & 0,8 & 0,8 \\
\hline Slovakya & 0,7 & 0,8 & 0,8 & 0,8 & 0,8 & 0,8 & 0,8 & 0,8 \\
\hline Macaristan & 0,7 & 0,8 & 0,8 & 0,8 & 0,8 & 0,8 & 0,8 & 0,8 \\
\hline Letonya & 0,7 & 0,7 & 0,8 & 0,8 & 0,8 & 0,8 & 0,8 & 0,8 \\
\hline Hirvatistan & 0,7 & 0,7 & 0,8 & 0,8 & 0,8 & 0,8 & 0,8 & 0,8 \\
\hline Karadağ & - & - & 0,8 & 0,8 & 0,8 & 0,8 & 0,8 & 0,8 \\
\hline Rusya & 0,7 & 0,7 & 0,8 & 0,8 & 0,8 & 0,8 & 0,8 & 0,8 \\
\hline Romanya & 0,7 & 0,7 & 0,8 & 0,8 & 0,8 & 0,8 & 0,8 & 0,8 \\
\hline Belarus & - & 0,7 & 0,8 & 0,8 & 0,8 & 0,8 & 0,8 & 0,8 \\
\hline Bulgaristan & 0,7 & 0,7 & 0,8 & 0,8 & 0,8 & 0,8 & 0,8 & 0,8 \\
\hline Kazakistan & 0,7 & 0,7 & 0,8 & 0,8 & 0,8 & 0,8 & 0,8 & 0,8 \\
\hline Surbistan & 0,7 & 0,7 & 0,8 & 0,8 & 0,8 & 0,8 & 0,8 & 0,8 \\
\hline Gürcistan & - & 0,7 & 0,7 & 0,7 & 0,8 & 0,8 & 0,8 & 0,8 \\
\hline Türkiye & 0,6 & 0,7 & 0,7 & 0,8 & 0,8 & 0,8 & 0,8 & 0,8 \\
\hline Arnavutluk & 0,6 & 0,7 & 0,7 & 0,8 & 0,8 & 0,8 & 0,8 & 0,8 \\
\hline Bosna Hersek & - & - & 0,7 & 0,7 & 0,7 & 0,7 & 0,7 & 0,7 \\
\hline Ermenistan & 0,6 & 0,6 & 0,7 & 0,7 & 0,7 & 0,7 & 0,7 & 0,7 \\
\hline Ukrayna & 0,7 & 0,7 & 0,7 & 0,7 & 0,7 & 0,7 & 0,7 & 0,7 \\
\hline Özbekistan & - & 0,6 & 0,7 & 0,7 & 0,7 & 0,7 & 0,7 & 0,7 \\
\hline Moldova & 0,7 & 0,6 & 0,7 & 0,7 & 0,7 & 0,7 & 0,7 & 0,7 \\
\hline Kırgızistan & 0,6 & 0,6 & 0,6 & 0,6 & 0,6 & 0,7 & 0,7 & 0,7 \\
\hline Tacikistan & 0,6 & 0,5 & 0,6 & 0,6 & 0,6 & 0,6 & 0,6 & 0,6 \\
\hline
\end{tabular}




\section{Sanayi Sektöründeki İstihdam Oranı}

Bilgi ekonomisinde işgücü talebinde gözle görür farklılıklar söz konusudur. Bu ekonomide bilgi teknolojilerindeki gelişmeler ve bu teknolojilere uygun yetişmiş insan gücünün ön plana çıkması dikkat çekmektedir. Rekabet üstünlüğü için nitelikli işgücünün varlığı işletmelere avantaj sağlamaktadır.

Toplam istihdam içinde sanayi sektöründeki istihdam rakamlarının gösterildiği Tablo 3'te 2006-2016 yılları arasında rakamlarda çok büyük değişikliklerin olmadığı görülmektedir. 2016 yılı itibariyle sanayide istihdam oranının en yüksek olduğu ülke \%38,1 ile Çek Cumhuriyeti'dir. Bu ülkeyi \%37,5 ile Özbekistan, \%36,5 ile Slovakya takip etmektedir. En düşük istihdam oranı ise \%15,8 ile Ermenistan'a aittir. Tablo incelendiğinde 2016 yllında sanayi sektöründeki istihdam oranın 2006 yılına göre Bosna Hersek, Gürcistan, Kazakistan, Kırgızistan, Polonya, Tacikistan ve Özbekistan da artarken diğer ülkelerde azaldığı görülmektedir.

Tablo 3. Sanayi Sektöründeki İstihdam (Toplam İstihdamın Yüzdesi, 2006-2016)

\begin{tabular}{|c|c|c|c|c|c|c|c|c|c|c|c|}
\hline Ülkeler & 2006 & 2007 & 2008 & 2009 & 2010 & 2011 & 2012 & 2013 & 2014 & 2015 & 2016 \\
\hline Arnavutluk & 20,5 & 18,7 & 20,8 & 19,9 & 19,4 & 18,9 & 16,5 & 17,2 & 17,5 & 18,6 & 18,5 \\
\hline Ermenistan & 18,5 & 19,0 & 19,2 & 17,1 & 17,4 & 16,7 & 17,7 & 17,0 & 16,7 & 15,9 & 15,8 \\
\hline Bulgaristan & 34,5 & 35,5 & 36,4 & 35,2 & 33,0 & 31,5 & 31,3 & 30,2 & 30,1 & 29,9 & 29,8 \\
\hline Bosna Hersek & 27,9 & 28,8 & 29,4 & 29,5 & 29,1 & 29,5 & 29,0 & 29,2 & 30,0 & 37,5 & 32,3 \\
\hline Belarus & 35,6 & 35,8 & 37,2 & 35,8 & 34,6 & 35,6 & 34,8 & 34,4 & 33,7 & 32,4 & 31,5 \\
\hline Çek Cum. & 40,0 & 40,2 & 40,5 & 38,6 & 38,0 & 38,5 & 38,1 & 37,5 & 38,0 & 38,0 & 38,1 \\
\hline Estonya & 33,5 & 35,1 & 35,3 & 31,4 & 30,3 & 32,4 & 31,1 & 30,3 & 30,1 & 30,7 & 29,7 \\
\hline Gürcistan & 9,0 & 10,4 & 10,4 & 9,6 & 10,3 & 11,0 & 11,5 & 11,1 & 11,7 & 12,2 & 12,4 \\
\hline Hirvatistan & 29,3 & 30,6 & 30,9 & 29,0 & 27,5 & 28,0 & 27,9 & 27,6 & 27,0 & 26,7 & 27,0 \\
\hline Macaristan & 32,3 & 32,5 & 32,2 & 31,2 & 30,7 & 30,8 & 29,8 & 29,9 & 30,5 & 30,3 & 30,4 \\
\hline Kazakistan & 18,4 & 18,9 & 18,9 & 18,6 & 18,7 & 19,0 & 19,4 & 19,8 & 20,5 & 20,6 & 20,9 \\
\hline Kirg1zistan & 19,4 & 20,3 & 20,6 & 22,3 & 22,8 & 22,8 & 21,7 & 20,2 & 20,4 & 20,9 & 22,1 \\
\hline Litvanya & 29,6 & 30,5 & 30,5 & 26,8 & 24,6 & 24,6 & 25,1 & 25,5 & 24,7 & 25,1 & 25,1 \\
\hline Letonya & 27,4 & 28,6 & 29,4 & 24,3 & 23,1 & 22,9 & 23,5 & 23,9 & 23,8 & 23,6 & 24,1 \\
\hline Moldova & 18,2 & 18,7 & 19,7 & 19,3 & 18,7 & 18,7 & 19,3 & 17,7 & 17,9 & 17,8 & 17,1 \\
\hline Karadă̆ & 18,8 & 17,5 & 21,5 & 19,8 & 19,0 & 19,0 & 17,4 & 18,1 & 17,5 & 17,6 & 18,0 \\
\hline Polonya & 30,0 & 30,7 & 31,9 & 31,1 & 30,3 & 30,7 & 30,4 & 30,5 & 30,5 & 30,5 & 31,4 \\
\hline Romanya & 30,7 & 31,4 & 31,6 & 30,0 & 28,3 & 28,6 & 28,2 & 28,3 & 28,9 & 28,5 & 29,9 \\
\hline Rusya & 29,3 & 29,2 & 28,9 & 27,5 & 27,7 & 27,5 & 27,8 & 27,7 & 27,5 & 27,2 & 26,9 \\
\hline Surbistan & 29,3 & 29,5 & 26,2 & 26,1 & 22,3 & 26,8 & 26,5 & 25,9 & 24,7 & 24,5 & 24,4 \\
\hline Slovakya & 38,8 & 39,4 & 40,1 & 37,9 & 37,1 & 37,5 & 37,5 & 35,8 & 35,4 & 36,1 & 36,5 \\
\hline Slovenya & 35,5 & 35,2 & 35,1 & 33,2 & 32,6 & 31,7 & 31,0 & 31,0 & 30,9 & 32,0 & 33,2 \\
\hline Tacikistan & 16,0 & 16,1 & 15,7 & 15,7 & 15,5 & 13,3 & 13,3 & 13,8 & 14,9 & 16,1 & 16,6 \\
\hline Türkiye & 26,8 & 26,7 & 26,8 & 25,3 & 26,2 & 26,5 & 26,0 & 26,4 & 27,9 & 27,2 & 26,8 \\
\hline Ukrayna & 27,8 & 27,8 & 26,5 & 25,9 & 25,7 & 25,7 & 25,9 & 24,8 & 26,1 & 24,7 & 25,0 \\
\hline Özbekistan & 33,5 & 33,8 & 36,1 & 37,1 & 37,1 & 37,0 & 37,1 & 37,3 & 37,6 & 37,8 & 37,5 \\
\hline
\end{tabular}


Türkiye' de toplam istihdam içindeki sanayi sektörünün payı 2016 yılı itibariyle \%26,8'dir. 2006-2016 dönemi değerlendirildiğinde sanayi sektöründeki istihdam oranı yıllar itibariyle küçük oranlarda inişli çıkışlı bir seyir izlemektedir. Tabloda yer alan diğer ülkeler ile karşılaştırıldığında Türkiye toplam istihdam içindeki sanayi sektörünün payına göre on dördüncü sırada yer almaktadır.

\section{Hizmetler Sektöründeki İstihdam Oranı}

Bilgi ekonomisinde hizmet sektörünün ön plana çıktığı görülmektedir. Özellikle gelişmiş ülkelerde istihdam yapısındaki bu değişim açıkça görülmektedir. Toplam istihdam içinde hizmet sektörünün almış olduğu payın yüksek olması, bilgi ekonomisine geçişte bir gösterge olarak kabul edilebilir.

Tablo 4. Hizmet Sektöründeki İstihdam (Toplam İstihdamın Yüzdesi, 2006-2016)

\begin{tabular}{|c|c|c|c|c|c|c|c|c|c|c|c|}
\hline Ülkeler & 2006 & 2007 & 2008 & 2009 & 2010 & 2011 & 2012 & 2013 & 2014 & 2015 & 2016 \\
\hline Arnavutluk & 27,2 & 33,4 & 31,9 & 36,0 & 36,7 & 35,7 & 36,0 & 38,0 & 39,6 & 40,0 & 40,9 \\
\hline Ermenistan & 42,9 & 44,5 & 43,4 & 43,5 & 44,0 & 44,4 & 45,0 & 46,7 & 48,4 & 48,8 & 50,1 \\
\hline Bulgaristan & 57,4 & 57,0 & 56,1 & 57,7 & 60,2 & 61,8 & 62,2 & 63,2 & 62,9 & 63,2 & 63,5 \\
\hline Bosna Hersek & 48,1 & 48,2 & 48,3 & 50,3 & 51,2 & 51,3 & 51,6 & 51,9 & 52,9 & 44,6 & 48,5 \\
\hline Belarus & 51,4 & 52,1 & 51,5 & 53,0 & 54,5 & 54,5 & 55,3 & 56,0 & 56,8 & 58,1 & 58,7 \\
\hline Çek Cumh. & 56,3 & 56,2 & 56,3 & 58,3 & 58,9 & 58,6 & 58,8 & 59,5 & 59,2 & 59,0 & 59,0 \\
\hline Estonya & 61,4 & 60,1 & 60,8 & 64,5 & 65,5 & 63,2 & 64,4 & 65,5 & 66,0 & 65,4 & 66,4 \\
\hline Gürcistan & 35,6 & 36,2 & 39,3 & 40,3 & 41,5 & 41,7 & 42,8 & 44,0 & 44,7 & 46,0 & 46,4 \\
\hline Hirvatistan & 56,4 & 57,0 & 56,3 & 57,7 & 58,3 & 57,5 & 59,8 & 61,6 & 63,5 & 64,1 & 65,4 \\
\hline Macaristan & 62,9 & 62,9 & 63,5 & 64,2 & 64,8 & 64,3 & 65,1 & 65,3 & 64,8 & 64,8 & 64,5 \\
\hline Kazakistan & 50,0 & 49,9 & 50,9 & 52,3 & 53,0 & 54,6 & 55,1 & 56,0 & 59,4 & 61,4 & 61,3 \\
\hline Kırgizistan & 44,3 & 45,2 & 45,3 & 47,4 & 47,3 & 47,9 & 48,2 & 48,1 & 48,0 & 49,8 & 51,1 \\
\hline Litvanya & 56,6 & 58,1 & 61,4 & 64,2 & 66,6 & 67,0 & 66,1 & 66,1 & 66,1 & 65,9 & 66,9 \\
\hline Letonya & 61,2 & 61,2 & 62,6 & 66,9 & 68,3 & 68,2 & 68,2 & 68,0 & 68,6 & 68,4 & 68,2 \\
\hline Moldova & 48,2 & 48,5 & 49,3 & 52,5 & 53,8 & 53,7 & 54,3 & 53,5 & 51,6 & 48,0 & 49,2 \\
\hline Karadă̆ & 72,8 & 73,8 & 70,9 & 73,9 & 74,8 & 75,5 & 77,0 & 77,4 & 76,0 & 74,7 & 74,4 \\
\hline Polonya & 54,2 & 54,5 & 54,1 & 55,6 & 56,6 & 56,4 & 57,0 & 57,5 & 58,0 & 57,9 & 58,0 \\
\hline Romanya & 38,7 & 39,1 & 39,7 & 40,9 & 40,7 & 42,2 & 42,1 & 42,5 & 42,7 & 46,0 & 47,0 \\
\hline Rusya & 60,7 & 61,8 & 62,4 & 64,1 & 64,5 & 64,9 & 64,9 & 65,3 & 65,8 & 66,1 & 66,3 \\
\hline Surbistan & 50,2 & 49,7 & 48,7 & 50,1 & 55,0 & 52,0 & 52,6 & 52,9 & 55,5 & 56,1 & 57,0 \\
\hline Slovakya & 56,8 & 56,4 & 55,9 & 58,5 & 59,7 & 59,4 & 59,2 & 60,9 & 61,1 & 60,7 & 60,6 \\
\hline Slovenya & 54,9 & 54,9 & 56,3 & 57,7 & 58,6 & 59,7 & 60,6 & 60,5 & 59,4 & 60,9 & 61,8 \\
\hline Tacikistan & 27,9 & 29,1 & 29,8 & 31,2 & 31,4 & 30,8 & 31,8 & 31,6 & 31,4 & 32,1 & 32,7 \\
\hline Türkiye & 49,2 & 49,8 & 49,5 & 51,8 & 50,1 & 49,4 & 50,4 & 50,7 & 51,1 & 52,4 & 53,7 \\
\hline Ukrayna & 54,6 & 55,6 & 57,7 & 53,9 & 54,0 & 54,0 & 54,2 & 55,2 & 59,1 & 60,1 & 60,0 \\
\hline Özbekistan & 32,3 & 33,5 & 34,3 & 34,7 & 35,7 & 36,7 & 37,4 & 38,1 & 38,5 & 39,3 & 40,6 \\
\hline
\end{tabular}


Toplam istihdam içindeki hizmet sektörünün almış olduğu paylara ilişkin değerler yukarıdaki tabloda gösterilmektedir (Bkz. Tablo 4). 2016 yılı itibariyle Tacikistan dışındaki diğer ülkelere ait rakamların \%40’ın üzerinde olduğu görülmektedir. Bu durum yukarıda bahsedildiği gibi bilgi ekonomisinde hizmetler sektörünün ön plana çıktığını göstermektedir. Ülkelerin tamamında hizmetler sektörünün istihdam içindeki payı yıllar itibariyle artmıştır. Tablo incelendiğinde toplam istihdam içinde hizmet sektörüne ait en büyük pay \%74,4 ile Karadağ’a aittir. Bu ülkeyi \%68,2 ile Letonya, \%66,4 ile de Estonya takip etmektedir. Hizmetler sektörünün payının en düşük olduğu ülke \%32,7 ile Tacikistan'dır. 2016 yılında Türkiye'deki hizmetler sektörünün payı ise \%53,7'dir. İçinde bulunduğu gruptaki diğer ülkeler ile karşılaştırıldığında bu istihdam oranının on altıncı sırada olduğu görülmektedir.

\section{Ekonomik Rejim}

\section{Mal ve Hizmet ihracatı}

Küreselleşme ile birlikte diş ticaretin önemi ve etkisi her geçen gün daha da artmaktadır. Tablo 5 incelendiğinde 2006-2016 döneminde ihracat rakamlarında artış ve azalışların olduğu görülmektedir. Gerek ülkenin kendi ekonomik ve siyasi yapısından kaynaklanan nedenler gerekse küresel ölçekte yaşanan krizler ihracat rakamlarının dalgalı bir seyir izlemesine neden olmuştur.

Tablo 5'e göre ülkeler arasında GSYİH içindeki mal ve hizmet ihracat oranın en büyük ülke Slovakya olmuştur (\% 94,6). Bu ülkeyi \%89,5 oranıyla Macaristan ve \%79,5 oranıyla Çek Cumhuriyeti takip etmektedir. Dış ticaretin en düşük olduğu ülke ise \%13,3 oranıyla Tacikistan'dır. 2016 yılı itibariyle Türkiye'deki mal ve hizmetler ihracatı oranı \%22'dir. Bu oran 2016 yılında Türkiye'nin ihracat bakımından tablodaki birçok ülkeyi geriden takip ettiğine işaret etmektedir ve tabloda yer alan diğer ülkeler ile karşılaştırıldığında Türkiye ihracat payına göre yirmi dördüncü sırada yer almaktadır. 
Tablo 5. Mal ve Hizmet İhracatı (GSYİH' nın Yüzdesi, 2006-2016)

\begin{tabular}{|c|c|c|c|c|c|c|c|c|c|c|c|}
\hline Ülkeler & 2006 & 2007 & 2008 & 2009 & 2010 & 2011 & 2012 & 2013 & 2014 & 2015 & 2016 \\
\hline Arnavutluk & 24,9 & 28,1 & 25,3 & 25,2 & 28,0 & 29,2 & 28,9 & 28,9 & 28,2 & 27,3 & 28,9 \\
\hline Ermenistan & 23,4 & 19,2 & 15,0 & 15,5 & 20,8 & 23,8 & 27,6 & 28,4 & 28,6 & 29,7 & 33,1 \\
\hline Bulgaristan & 47,3 & 52,4 & 52,5 & 42,3 & 50,2 & 59,1 & 60,8 & 64,7 & 65,0 & 64,1 & 64,0 \\
\hline Bosna Hersek & 35,0 & 27,1 & 26,8 & 25,0 & 29,7 & 32,0 & 32,3 & 33,7 & 34,0 & 34,6 & 35,4 \\
\hline Belarus & 60,1 & 60,9 & 60,9 & 50,5 & 51,4 & 78,5 & 78,8 & 58,3 & 54,9 & 58,0 & 62,5 \\
\hline Çek Cum. & 65,2 & 66,4 & 63,2 & 58,7 & 66,0 & 71,3 & 76,2 & 76,9 & 82,5 & 81,0 & 79,5 \\
\hline Estonya & 63,5 & 63,2 & 66,8 & 60,8 & 75,1 & 86,5 & 86,0 & 84,3 & 82,6 & 78,6 & 79,0 \\
\hline Gürcistan & 32,9 & 31,2 & 28,6 & 29,7 & 35,0 & 36,2 & 38,2 & 44,7 & 42,9 & 44,7 & 43,6 \\
\hline Hirvatistan & 39,7 & 39,0 & 38,5 & 34,5 & 37,6 & 40,3 & 41,5 & 42,8 & 45,3 & 48,2 & 49,0 \\
\hline Macaristan & 74,0 & 77,9 & 79,3 & 74,4 & 81,8 & 86,7 & 86,4 & 85,7 & 87,7 & 90,2 & 89,5 \\
\hline Kazakistan & 51,0 & 49,3 & 57,1 & 41,8 & 44,2 & 46,5 & 44,1 & 38,6 & 39,3 & 28,5 & 31,8 \\
\hline Kurgizistan & 41,7 & 52,9 & 53,5 & 54,7 & 51,6 & 54,5 & 44,4 & 42,3 & 37,4 & 35,2 & 35,8 \\
\hline Litvanya & 55,6 & 50,4 & 57,1 & 51,9 & 65,3 & 75,0 & 81,6 & 84,1 & 81,1 & 75,8 & 74,5 \\
\hline Letonya & 40,0 & 38,5 & 39,5 & 42,6 & 53,7 & 57,8 & 61,3 & 60,3 & 60,7 & 60,4 & 60,0 \\
\hline Moldova & 45,3 & 47,5 & 40,8 & 36,9 & 39,2 & 45,0 & 43,5 & 43,3 & 41,5 & 42,8 & 43,3 \\
\hline Karadağ & 40,6 & 43,0 & 39,5 & 34,3 & 37,0 & 42,3 & 43,7 & 41,3 & 40,1 & 42,1 & 40,5 \\
\hline Polonya & 37,9 & 38,6 & 37,9 & 37,2 & 40,1 & 42,6 & 44,4 & 46,3 & 47,6 & 49,5 & 52,3 \\
\hline Romanya & 32,1 & 28,4 & 26,3 & 26,5 & 32,6 & 37,0 & 37,5 & 39,7 & 41,2 & 41,0 & 41,3 \\
\hline Rusya & 33,7 & 30,2 & 31,3 & 27,9 & 29,2 & 28,0 & 26,9 & 25,8 & 27,1 & 28,6 & 25,7 \\
\hline Sirbistan & 30,3 & 28,4 & 29,1 & 26,8 & 32,9 & 34,0 & 36,9 & 41,2 & 43,4 & 46,7 & 50,0 \\
\hline Slovakya & 81,0 & 83,3 & 80,0 & 67,6 & 76,3 & 85,0 & 91,4 & 93,8 & 91,9 & 93,0 & 94,6 \\
\hline Slovenya & 64,7 & 67,6 & 66,1 & 57,2 & 64,3 & 70,4 & 73,1 & 74,5 & 75,8 & 77,0 & 77,7 \\
\hline Tacikistan & 23,2 & 20,6 & 16,8 & 15,2 & 14,9 & 16,4 & 17,2 & 11,3 & 9,1 & 10,5 & 13,3 \\
\hline Türkiye & 21,7 & 21,2 & 22,8 & 22,6 & 20,4 & 22,3 & 23,7 & 22,3 & 23,8 & 23,3 & 22,0 \\
\hline Ukrayna & 46,6 & 44,8 & 46,9 & 46,4 & 47,1 & 49,8 & 35,4 & 43,0 & 48,6 & 52,6 & 49,3 \\
\hline Özbekistan & 36,5 & 39,7 & 41,1 & 34,2 & 31,7 & 32,7 & 27,3 & 26,6 & 23,1 & 19,5 & 18,9 \\
\hline
\end{tabular}

Kaynak: https://data.worldbank.org

\section{Ticaret özgürlüğ̈̈̈}

Ticaret özgürlüğü ile ülkeler arasında dış ticaretin ne kadar serbest olduğu ve uluslararası sermaye hareketlerinin hangi oranda açıkça gerçekleştiği ölçülmektedir. Bu değişken, malların ve hizmetlerin serbest bir şekilde piyasadaki dolaşımını ve bireylerin alıcı veya satıcı olarak serbest bir şekilde piyasadaki etkileşimini ortaya koymaktadır. Ticaret özgürlügüu, gümrük tarifeleri, ticaret kotası, ticaret kısitlamamaları, ihracat-ithalat vergileri olarak kendini göstermektedir. Bu değişken KAM yönteminde “Tarife ve Tarife Dışı Engeller” şeklinde değerlendirilmiştir. 
Tablo 6. Ticaret Özgürlüğ̈̈

\begin{tabular}{|c|c|c|c|c|c|c|c|c|c|c|c|}
\hline Ülkeler & 2006 & 2007 & 2008 & 2009 & 2010 & 2011 & 2012 & 2013 & 2014 & 2015 & 2016 \\
\hline Arnavutluk & 62,4 & 73,2 & 75,8 & 75,8 & 85,8 & 79,8 & 79,8 & 79,8 & 87,5 & 87,8 & 87,6 \\
\hline Ermenistan & 80,6 & 85,6 & 85 & 86,4 & 80,5 & 85,5 & 85,4 & 85,4 & 85,5 & 85,4 & 85,6 \\
\hline Belarus & 67,2 & 67,2 & 52,2 & 67,2 & 80,3 & 80,3 & 80,4 & 80,8 & 81,4 & 81 & 79,0 \\
\hline Bosna Hersek & 75,2 & 80,2 & 79,8 & 77,2 & 80,8 & 86 & 86 & 86,4 & 86,9 & 87,2 & 87,0 \\
\hline Bulgaristan & 65,8 & 70,8 & 86 & 85,8 & 87,4 & 87,6 & 87,1 & 86,8 & 87,8 & 88 & 88,0 \\
\hline Hırvatistan & 78,4 & 87,8 & 87,6 & 87,6 & 87,8 & 87,6 & 87,5 & 87,5 & 87,4 & 87,2 & 87,4 \\
\hline Çek Cum. & 82,4 & 86,6 & 86 & 85,8 & 87,5 & 87,6 & 87,1 & 86,8 & 87,8 & 88 & 88,0 \\
\hline Estonya & 82,4 & 86,6 & 86 & 85,8 & 87,5 & 87,6 & 87,1 & 86,8 & 87,8 & 88 & 88,0 \\
\hline Gürcistan & 67,6 & 71,8 & 71 & 80,6 & 89,1 & 89,2 & 89,2 & 89,2 & 88,6 & 88,6 & 88,6 \\
\hline Macaristan & 82,4 & 86,6 & 86 & 85,8 & 87,5 & 87,6 & 87,1 & 86,8 & 87,8 & 88 & 88,0 \\
\hline Kazakistan & 69,2 & 69,2 & 86,2 & 86,2 & 85,9 & 80,9 & 79,6 & 78,2 & 78,2 & 79 & 77,4 \\
\hline Kırgızistan & 76,4 & 81,4 & 81,4 & 87,6 & 75,9 & 63,2 & 63,2 & 75,4 & 75,2 & 80,2 & 75,0 \\
\hline Letonya & 82,4 & 86,6 & 86 & 85,8 & 87,5 & 87,6 & 87,1 & 86,8 & 87,8 & 88 & 88,0 \\
\hline Litvanya & 82,4 & 86,6 & 86 & 85,8 & 87,5 & 87,6 & 87,1 & 86,8 & 87,8 & 88 & 88,0 \\
\hline Moldova & 79,4 & 79,4 & 79,2 & 81,6 & 79,9 & 80,2 & 79 & 80,0 & 80,1 & 79,8 & 73,6 \\
\hline Polonya & 82,4 & 86,6 & 86 & 85,8 & 87,5 & 87,6 & 87,1 & 86,8 & 87,8 & 88 & 88,0 \\
\hline Romanya & 68,4 & 84 & 86 & 85,8 & 87,5 & 87,6 & 87,1 & 86,8 & 87,8 & 88 & 88,0 \\
\hline Rusya & 62,6 & 62,6 & 44,2 & 60,8 & 68,4 & 68,2 & 68,2 & 77,4 & 74,6 & 75 & 72,4 \\
\hline Surbistan & - & - & - & 78 & 75,2 & 75,2 & 77,9 & 77,9 & 77,0 & 78,2 & 77,8 \\
\hline Karadağ & - & - & - & 80,2 & 83,2 & 83,6 & 83,6 & 83 & 83,1 & 84,8 & 84,8 \\
\hline Slovakya & 82,4 & 86,6 & 86 & 85,8 & 87,5 & 87,6 & 87,1 & 86,8 & 87,8 & 88 & 88,0 \\
\hline Slovenya & 82,4 & 86,6 & 86 & 85,8 & 87,5 & 87,6 & 87,1 & 86,8 & 87,8 & 88 & 88,0 \\
\hline Tacikistan & 70,8 & 71,0 & 77,8 & 82,6 & 82,5 & 82,5 & 82,5 & 78,2 & 73,2 & 74,6 & 68,6 \\
\hline Türkiye & 81,0 & 81,0 & 86,8 & 86,6 & 86,4 & 85,4 & 85,4 & 85,2 & 84,5 & 84,6 & 84,4 \\
\hline Ukrayna & 77,2 & 77,2 & 82,2 & 84 & 82,6 & 85,2 & 84,4 & 84,4 & 86,2 & 85,8 & 85,8 \\
\hline Özbekistan & 68,2 & 68,2 & 68,4 & 65,4 & 65,1 & 66,2 & 66,1 & 66,1 & 66,1 & 69,8 & 65,6 \\
\hline
\end{tabular}

Kaynak: https://www.heritage.org/index/explore

Yukarıdaki tablo incelendiğinde 2006-2016 dönemine baktığımızda ülkelerin çoğunun ticaret özgürlüğü oranlarında bir artışın söz konusu olduğu görülmektedir (Bkz. tablo 6). 2016 yılı itibariyle ülkelerin ticaret özgürlüğü değerlerinin \%88,6 ile \%65,6 arasında değiştiği görülmektedir. En yüksek değer \%88,6 ile Gürcistan'a aitken bu ülkeyi \%87,6 ile Arnavutluk ve $\% 85,8$ ile Ukrayna takip etmektedir. Ticaret özgürlügü değerinin en düşük olduğu ülke Özbekistan olmuştur $(\% 65,6)$. Türkiye ye ait ticaret özgürlüğü oranı ise $\% 84,4$ olup, bu oran içinde bulunduğu gruptaki diğer ülkelerle karşılaştırıldığına on yedinci sırada yer almaktadır.

\section{Kurumlar}

\section{Hükümet Etkinliği}

Hükümet etkinliği, kamu hizmetlerinin niteliğini, devlet hizmetinin niteliğini ve siyasal baskılardan bağımsızlığın derecesini, politika oluşturma ve uygulama niteliğini ve bu gibi politikalara hükümetin sağladığı taahhüttün güvenilirliğine dair algıyı yansıtır. Tahmin sonucu -2.5 (zayıf) ile 2.5 (güçlü) arasında dağılım göstermektedir (www.govindicators.org). 


\section{Tablo 7. Hükümet Etkinliği}

\begin{tabular}{|c|c|c|c|c|c|c|c|c|c|c|c|}
\hline Ülkeler & 2006 & 2007 & 2008 & 2009 & 2010 & 2011 & 2012 & 2013 & 2014 & 2015 & 2016 \\
\hline Arnavutluk & $-0,5$ & $-0,4$ & $-0,4$ & $-0,3$ & $-0,3$ & $-0,2$ & $-0,3$ & $-0,3$ & $-0,1$ & 0,0 & 0,0 \\
\hline Ermenistan & $-0,3$ & $-0,4$ & $-0,2$ & 0,0 & $-0,2$ & $-0,1$ & 0,0 & 0,1 & $-0,2$ & $-0,2$ & $-0,1$ \\
\hline Bulgaristan & $-0,1$ & 0,0 & 0,0 & 0,2 & 0,1 & 0,1 & 0,1 & 0,2 & 0,1 & 0,2 & 0,3 \\
\hline Bosna Hersek & $-0,6$ & $-0,8$ & $-0,6$ & $-0,7$ & $-0,7$ & $-0,7$ & $-0,5$ & $-0,4$ & $-0,5$ & $-0,5$ & $-0,4$ \\
\hline Belarus & $-1,1$ & $-1,1$ & $-1,1$ & $-1,1$ & $-1,1$ & $-1,1$ & $-0,9$ & $-0,9$ & $-0,5$ & $-0,5$ & $-0,5$ \\
\hline Çek Cum. & 1,1 & 0,9 & 1,0 & 0,9 & 0,9 & 0,9 & 0,9 & 0,9 & 1,0 & 1,0 & 1,1 \\
\hline Estonya & 1,2 & 1,0 & 1,2 & 1,0 & 1,1 & 1,1 & 1,0 & 1,0 & 1,0 & 1,1 & 1,1 \\
\hline Gürcistan & $-0,2$ & 0,1 & 0,3 & 0,3 & 0,3 & 0,6 & 0,6 & 0,6 & 0,5 & 0,4 & 0,5 \\
\hline Hurvatistan & 0,6 & 0,5 & 0,6 & 0,6 & 0,6 & 0,6 & 0,7 & 0,7 & 0,7 & 0,5 & 0,5 \\
\hline Macaristan & 0,9 & 0,7 & 0,7 & 0,7 & 0,7 & 0,7 & 0,6 & 0,7 & 0,5 & 0,5 & 0,5 \\
\hline Kazakistan & $-0,4$ & $-0,6$ & $-0,5$ & $-0,4$ & $-0,4$ & $-0,4$ & $-0,4$ & $-0,5$ & 0,0 & $-0,1$ & $-0,1$ \\
\hline Kırgızistan & $-0,8$ & $-0,8$ & $-0,8$ & $-1,0$ & $-0,7$ & $-0,6$ & $-0,6$ & $-0,7$ & $-0,9$ & $-0,9$ & $-0,9$ \\
\hline Litvanya & 0,7 & 0,7 & 0,6 & 0,7 & 0,7 & 0,7 & 0,8 & 0,8 & 1,0 & 1,2 & 1,1 \\
\hline Letonya & 0,7 & 0,5 & 0,6 & 0,6 & 0,7 & 0,7 & 0,8 & 0,9 & 1,0 & 1,1 & 1,0 \\
\hline Moldova & $-0,8$ & $-0,8$ & $-0,8$ & $-0,6$ & $-0,7$ & $-0,6$ & $-0,6$ & $-0,4$ & $-0,4$ & $-0,7$ & $-0,6$ \\
\hline Karadağ & $-0,1$ & $-0,2$ & 0,0 & 0,0 & 0,1 & 0,1 & 0,1 & 0,2 & 0,3 & 0,2 & 0,1 \\
\hline Polonya & 0,4 & 0,4 & 0,5 & 0,5 & 0,6 & 0,6 & 0,7 & 0,7 & 0,8 & 0,8 & 0,7 \\
\hline Romanya & $-0,2$ & $-0,3$ & $-0,3$ & $-0,4$ & $-0,3$ & $-0,3$ & $-0,3$ & $-0,1$ & 0,0 & $-0,1$ & $-0,2$ \\
\hline Rusya & $-0,4$ & $-0,4$ & $-0,4$ & $-0,4$ & $-0,5$ & $-0,5$ & $-0,4$ & $-0,4$ & $-0,1$ & $-0,2$ & $-0,2$ \\
\hline Slovakya & 0,9 & 0,7 & 0,9 & 0,9 & 0,8 & 0,8 & 0,8 & 0,8 & 0,9 & 0,8 & 0,9 \\
\hline Slovenya & 1,0 & 0,9 & 1,2 & 1,2 & 1,0 & 1,0 & 1,0 & 1,0 & 1,0 & 1,0 & 1,1 \\
\hline Tacikistan & $-1,1$ & $-1,1$ & $-1,1$ & $-1,1$ & $-0,9$ & $-0,9$ & $-0,9$ & $-1,1$ & $-0,8$ & $-0,8$ & $-1,0$ \\
\hline Türkiye & 0,1 & 0,3 & 0,3 & 0,3 & 0,3 & 0,3 & 0,4 & 0,4 & 0,4 & 0,2 & 0,1 \\
\hline Ukrayna & $-0,5$ & $-0,7$ & $-0,7$ & $-0,8$ & $-0,8$ & $-0,8$ & $-0,6$ & $-0,6$ & $-0,4$ & $-0,5$ & $-0,6$ \\
\hline Özbekistan & $-1,2$ & $-1,1$ & $-0,9$ & $-0,6$ & $-0,7$ & $-0,7$ & $-0,9$ & $-0,9$ & $-0,6$ & $-0,7$ & $-0,6$ \\
\hline Sirbistan & $-0,2$ & $-0,2$ & $-0,2$ & 0,0 & 0,0 & $-0,1$ & $-0,1$ & $-0,1$ & 0,1 & 0,1 & 0,1 \\
\hline
\end{tabular}

Kaynak: www.govindicators.org

2006-2016 yılları arasında hükümet etkinliği göstergesine ait değerler Tablo 7’ de yer almaktadır. Tabloda yer alan değerler sistemin belirlemiş olduğu sınırlar arasında değişmektedir (The Worldwide Governance Indicators (WGI)'nin belirlediği -2,5 ile 2,5 arasinda).

Buna göre 2016 yılında hükümet etkinliği göstergesinin en düşük değeri -0,9 ile Kırgızistan' a ait iken, bu göstergenin en yüksek değeri 1,1 ile Çek Cumhuriyeti, Estonya, Litvanya ve Slovenya' ya aittir. Türkiye'deki hükümet etkinliği göstergesinin değeri 0,1'dir. Bu değere göre Türkiye on ikinci sırada yer almaktadır. 


\section{Düzenleme Niteliği}

Düzenleme niteliği, hükümetin, özel sektör kalkınmasına izin veren ve kalkınmaya teşvik eden sağlam politikaları ve yönetmelikleri oluşturma ve uygulama gücüne dair algıları yansıtır. Tahmin sonucu -2.5 (zayıf) ile 2.5 (güçlü) arasında dağılım göstermektedir (www.govindicators.org).

Tablo 8. Düzenleme Niteliği

\begin{tabular}{|l|r|r|r|r|r|r|r|r|r|r|r|}
\hline Ülkeler & $\mathbf{2 0 0 6}$ & $\mathbf{2 0 0 7}$ & $\mathbf{2 0 0 8}$ & $\mathbf{2 0 0 9}$ & $\mathbf{2 0 1 0}$ & $\mathbf{2 0 1 1}$ & $\mathbf{2 0 1 2}$ & $\mathbf{2 0 1 3}$ & $\mathbf{2 0 1 4}$ & $\mathbf{2 0 1 5}$ & $\mathbf{2 0 1 6}$ \\
\hline Arnavutluk & $-0,1$ & 0,1 & 0,1 & 0,2 & 0,2 & 0,2 & 0,2 & 0,2 & 0,2 & 0,2 & 0,2 \\
\hline Ermenistan & 0,3 & 0,3 & 0,3 & 0,3 & 0,3 & 0,3 & 0,3 & 0,3 & 0,2 & 0,2 & 0,2 \\
\hline Bulgaristan & 0,6 & 0,6 & 0,7 & 0,7 & 0,6 & 0,5 & 0,6 & 0,5 & 0,6 & 0,6 & 0,7 \\
\hline Bosna Hersek & $-0,5$ & $-0,3$ & $-0,2$ & $-0,1$ & $-0,1$ & 0,0 & $-0,1$ & $-0,1$ & $-0,1$ & $-0,2$ & $-0,2$ \\
\hline Belarus & $-1,6$ & $-1,4$ & $-1,2$ & $-1,1$ & $-1,1$ & $-1,2$ & $-1,1$ & $-1,1$ & $-1,0$ & $-1,0$ & $-0,9$ \\
\hline Çek Cum. & 1,1 & 1,0 & 1,2 & 1,3 & 1,3 & 1,2 & 1,1 & 1,1 & 1,0 & 1,1 & 1,0 \\
\hline Estonya & 1,3 & 1,4 & 1,4 & 1,4 & 1,4 & 1,4 & 1,4 & 1,4 & 1,7 & 1,7 & 1,7 \\
\hline Gürcistan & $-0,1$ & 0,3 & 0,5 & 0,5 & 0,6 & 0,7 & 0,7 & 0,8 & 0,9 & 0,9 & 1,0 \\
\hline Hırvatistan & 0,4 & 0,5 & 0,5 & 0,6 & 0,6 & 0,5 & 0,5 & 0,5 & 0,4 & 0,4 & 0,4 \\
\hline Macaristan & 1,2 & 1,2 & 1,2 & 1,1 & 1,0 & 1,0 & 1,0 & 0,9 & 0,8 & 0,8 & 0,6 \\
\hline Kazakistan & $-0,4$ & $-0,4$ & $-0,3$ & $-0,3$ & $-0,3$ & $-0,2$ & $-0,4$ & $-0,4$ & $-0,3$ & 0,0 & $-0,1$ \\
\hline Kırgizistan & $-0,7$ & $-0,4$ & $-0,4$ & $-0,3$ & $-0,3$ & $-0,2$ & $-0,3$ & $-0,3$ & $-0,4$ & $-0,5$ & $-0,4$ \\
\hline Litvanya & 1,0 & 1,1 & 1,1 & 1,0 & 1,0 & 0,9 & 1,1 & 1,2 & 1,2 & 1,3 & 1,1 \\
\hline Letonya & 1,0 & 1,0 & 1,0 & 1,0 & 1,0 & 1,0 & 1,0 & 1,0 & 1,2 & 1,1 & 1,1 \\
\hline Moldova & $-0,3$ & $-0,3$ & $-0,2$ & $-0,1$ & $-0,1$ & $-0,1$ & $-0,1$ & $-0,1$ & 0,0 & $-0,1$ & $-0,1$ \\
\hline Karadă & $-0,3$ & $-0,2$ & $-0,1$ & 0,0 & $-0,1$ & $-0,1$ & 0,0 & 0,1 & 0,1 & 0,2 & 0,2 \\
\hline Polonya & 0,7 & 0,8 & 0,8 & 1,0 & 1,0 & 0,9 & 1,0 & 1,0 & 1,1 & 1,0 & 1,0 \\
\hline Romanya & 0,5 & 0,5 & 0,6 & 0,6 & 0,6 & 0,7 & 0,6 & 0,6 & 0,6 & 0,6 & 0,6 \\
\hline Rusya & $-0,4$ & $-0,3$ & $-0,4$ & $-0,3$ & $-0,4$ & $-0,3$ & $-0,3$ & $-0,4$ & $-0,4$ & $-0,5$ & $-0,4$ \\
\hline Slovakya & 1,1 & 1,0 & 1,1 & 1,1 & 1,0 & 1,0 & 1,0 & 0,9 & 0,9 & 0,8 & 0,9 \\
\hline Slovenya & 0,8 & 0,8 & 0,8 & 0,9 & 0,8 & 0,7 & 0,6 & 0,6 & 0,7 & 0,6 & 0,6 \\
\hline Tacikistan & $-1,1$ & $-1,1$ & $-1,1$ & $-1,1$ & $-1,0$ & $-1,0$ & $-1,0$ & $-1,1$ & $-1,0$ & $-1,0$ & $-1,1$ \\
\hline Türkiye & 0,3 & 0,3 & 0,3 & 0,3 & 0,3 & 0,4 & 0,4 & 0,4 & 0,4 & 0,3 & 0,2 \\
\hline Ukrayna & $-0,5$ & $-0,4$ & $-0,5$ & $-0,6$ & $-0,5$ & $-0,6$ & $-0,6$ & $-0,6$ & $-0,6$ & $-0,6$ & $-0,4$ \\
\hline Özbekistan & $-1,6$ & $-1,5$ & $-1,4$ & $-1,5$ & $-1,6$ & $-1,6$ & $-1,6$ & $-1,6$ & $-1,7$ & $-1,6$ & $-1,6$ \\
\hline Surbistan & $-0,4$ & $-0,3$ & $-0,3$ & $-0,1$ & 0,0 & 0,0 & $-0,1$ & $-0,1$ & 0,1 & 0,2 & 0,1 \\
\hline
\end{tabular}

Kaynak: www.govindicators.org

Tablo 8 incelendiğinde 2006-2016 döneminde düzenlemenin niteliğine ilişkin verilerin belirlenen sınırlar içinde yer aldığ 1 görülmektedir (The Worldwide Governance Indicators (WGI)'nin belirlediği -2,5 ile 2,5 arasında). 2016 yılında bu göstergeye ait en yüksek değer 1,7 ile Slovakya'ya aitken, 1,1 değeriyle Litvanya ve Letonya bu ülkeyi izlemiştir. Bu göstergenin en küçük değeri ise Özbekistan’a aittir $(-1,6)$. Türkiye'deki düzenleme niteliği göstergesinin değeri ise 0,2'dir. Diğer ülkelerle karşılaştırıldığında Türkiye'nin almış olduğu bu değer on üçüncü sırada yer almaktadır. 


\section{Hukuk Kuralı}

Hukuk kuralı, memurların, toplum kurallarına ne ölçüde güven duydukları ve bağlı kaldıklarına dair algıyı ve bilhassa suç ve şiddet olasılığının yanı sıra sözleşme yaptırımının, mülkiyet haklarının, emniyet ve mahkemelerin niteliğini yansıtır. Tahmin sonucu -2.5 (zayıf) ile 2.5 (güçlü) arasında dağılım göstermektedir (www.govindicators.org).

Tablo 9. Hukuk Kuralı

\begin{tabular}{|c|c|c|c|c|c|c|c|c|c|c|c|}
\hline Ülkeler & 2006 & 2007 & 2008 & 2009 & 2010 & 2011 & 2012 & 2013 & 2014 & 2015 & 2016 \\
\hline Arnavutluk & $-0,7$ & $-0,6$ & $-0,6$ & $-0,5$ & $-0,4$ & $-0,5$ & $-0,5$ & $-0,5$ & $-0,3$ & $-0,3$ & $-0,3$ \\
\hline Ermenistan & $-0,5$ & $-0,5$ & $-0,3$ & $-0,5$ & $-0,5$ & $-0,4$ & $-0,4$ & $-0,3$ & $-0,4$ & $-0,4$ & $-0,1$ \\
\hline Bulgaristan & $-0,1$ & 0,0 & $-0,1$ & 0,0 & $-0,1$ & $-0,1$ & $-0,1$ & $-0,1$ & 0,0 & $-0,1$ & 0,0 \\
\hline Bosna Hersek & $-0,5$ & $-0,5$ & $-0,4$ & $-0,4$ & $-0,4$ & $-0,3$ & $-0,2$ & $-0,2$ & $-0,2$ & $-0,3$ & $-0,3$ \\
\hline Belarus & $-1,3$ & $-1,2$ & $-1,1$ & $-1,0$ & $-1,1$ & $-1,1$ & $-0,9$ & $-0,9$ & $-0,8$ & $-0,8$ & $-0,8$ \\
\hline Çek Cum. & 0,9 & 0,9 & 0,9 & 1,0 & 0,9 & 1,0 & 1,0 & 1,0 & 1,2 & 1,1 & 1,1 \\
\hline Estonya & 1,1 & 1,2 & 1,2 & 1,1 & 1,2 & 1,2 & 1,2 & 1,2 & 1,4 & 1,3 & 1,2 \\
\hline Gürcistan & $-0,5$ & $-0,3$ & $-0,3$ & $-0,2$ & $-0,2$ & $-0,1$ & 0,0 & 0,0 & 0,2 & 0,3 & 0,4 \\
\hline Hırvatistan & 0,0 & 0,1 & 0,1 & 0,2 & 0,2 & 0,2 & 0,2 & 0,3 & 0,3 & 0,2 & 0,4 \\
\hline Macaristan & 1,0 & 1,0 & 0,9 & 0,8 & 0,8 & 0,8 & 0,6 & 0,6 & 0,5 & 0,4 & 0,5 \\
\hline Kazakistan & $-1,0$ & $-0,9$ & $-0,8$ & $-0,6$ & $-0,6$ & $-0,6$ & $-0,7$ & $-0,7$ & $-0,6$ & $-0,4$ & $-0,4$ \\
\hline Kurgizistan & $-1,3$ & $-1,3$ & $-1,4$ & $-1,3$ & $-1,3$ & $-1,2$ & $-1,1$ & $-1,1$ & $-0,9$ & $-1,0$ & $-1,1$ \\
\hline Litvanya & 0,7 & 0,7 & 0,7 & 0,7 & 0,8 & 0,8 & 0,9 & 0,8 & 0,9 & 1,0 & 1,0 \\
\hline Letonya & 0,7 & 0,8 & 0,8 & 0,8 & 0,8 & 0,7 & 0,8 & 0,8 & 0,9 & 0,8 & 1,0 \\
\hline Moldova & $-0,5$ & $-0,5$ & $-0,4$ & $-0,4$ & $-0,4$ & $-0,3$ & $-0,3$ & $-0,4$ & $-0,2$ & $-0,4$ & $-0,5$ \\
\hline Karadă & $-0,3$ & $-0,2$ & $-0,1$ & 0,1 & 0,0 & 0,0 & 0,0 & 0,0 & 0,1 & 0,1 & 0,0 \\
\hline Polonya & 0,4 & 0,4 & 0,5 & 0,6 & 0,7 & 0,8 & 0,8 & 0,8 & 0,8 & 0,8 & 0,7 \\
\hline Romanya & $-0,1$ & $-0,1$ & 0,0 & 0,0 & 0,0 & 0,1 & 0,0 & 0,1 & 0,2 & 0,2 & 0,3 \\
\hline Rusya & $-1,0$ & $-1,0$ & $-1,0$ & $-0,8$ & $-0,8$ & $-0,7$ & $-0,8$ & $-0,8$ & $-0,7$ & $-0,8$ & $-0,8$ \\
\hline Slovakya & 0,5 & 0,5 & 0,6 & 0,5 & 0,6 & 0,6 & 0,5 & 0,5 & 0,5 & 0,5 & 0,7 \\
\hline Slovenya & 0,9 & 0,9 & 1,0 & 1,1 & 1,0 & 1,1 & 1,0 & 1,0 & 1,0 & 1,0 & 1,1 \\
\hline Tacikistan & $-1,2$ & $-1,3$ & $-1,3$ & $-1,3$ & $-1,2$ & $-1,2$ & $-1,2$ & $-1,3$ & $-1,0$ & $-1,1$ & $-1,2$ \\
\hline Türkiye & 0,0 & 0,0 & 0,1 & 0,1 & 0,1 & 0,1 & 0,0 & 0,1 & 0,0 & $-0,1$ & $-0,2$ \\
\hline Ukrayna & $-0,8$ & $-0,7$ & $-0,7$ & $-0,8$ & $-0,8$ & $-0,8$ & $-0,8$ & $-0,8$ & $-0,8$ & $-0,8$ & $-0,8$ \\
\hline Özbekistan & $-1,4$ & $-1,2$ & $-1,2$ & $-1,3$ & $-1,4$ & $-1,4$ & $-1,3$ & $-1,2$ & $-1,1$ & $-1,1$ & $-1,1$ \\
\hline Sirbistan & $-0,5$ & $-0,5$ & $-0,5$ & $-0,4$ & $-0,4$ & $-0,3$ & $-0,4$ & $-0,3$ & $-0,1$ & $-0,1$ & $-0,1$ \\
\hline
\end{tabular}

Kaynak: www.govindicators.org

2006-2016 yılları arasında hukuk kuralı göstergesine ait değerler Tablo 9'da yer almaktadır. Tabloda yer alan değerler sistemin belirlemiş olduğu aralıklar arasında değişmektedir (The Worldwide Governance Indicators (WGI)'nin belirlediği -2,5 ile 2,5 arasında).

Buna göre 2016 yılında hukuk kuralı göstergesinin en düşük değeri -1,2 ile Tacikistan'a ait iken, bu göstergenin en yüksek değeri 1,2 ile Estonya' ya aittir. Tablodan Türkiye'deki değerin ise 0,2 olduğu görülmektedir. Türkiye bu değişkene göre sıralamada on beşinci sırada yer almaktadır. 


\section{Eğitim ve İnsan Kaynakları}

\section{Doğumda Yaşam Beklentisi}

Yaşam beklentisi, toplumun genel sağlık durumunu ölçmek amacıyla kullanılan, sağlık ve toplum refahının en önemli göstergelerinden birisidir (Mahdian vd., 2016: s. 260). Yaşam beklentisi tahmini, bir ülkenin ekonomik ve sosyal gelişmişliğinin göstergesi olarak düşünülmektedir (Teker vd, 2012: s. 119).

Tablo 10. Doğumda Yaşam Beklentisi, Toplam (2006-2016)

\begin{tabular}{|c|c|c|c|c|c|c|c|c|c|c|c|}
\hline Ülkeler & 2006 & 2007 & 2008 & 2009 & 2010 & 2011 & 2012 & 2013 & 2014 & 2015 & 2016 \\
\hline Arnavutluk & 75,4 & 75,7 & 75,9 & 76,3 & 76,7 & 77,0 & 77,4 & 77,7 & 78,0 & 78,2 & 78,3 \\
\hline Ermenistan & 72,7 & 72,8 & 72,9 & 73,1 & 73,3 & 73,6 & 73,8 & 74,0 & 74,3 & 74,4 & 74,6 \\
\hline Bulgaristan & 72,6 & 72,7 & 73,0 & 73,4 & 73,5 & 74,2 & 74,3 & 74,9 & 74,5 & 74,6 & 74,6 \\
\hline Bosna Hersek & 75,4 & 75,5 & 75,6 & 75,8 & 75,9 & 76,1 & 76,2 & 76,4 & 76,6 & 76,7 & 76,9 \\
\hline Belarus & 69,4 & 70,2 & 70,5 & 70,4 & 70,4 & 70,6 & 72,0 & 72,5 & 73,0 & 73,6 & 73,8 \\
\hline Çek Cum. & 76,5 & 76,7 & 77,0 & 77,1 & 77,4 & 77,9 & 78,1 & 78,2 & 78,8 & 78,6 & 78,3 \\
\hline Estonya & 72,7 & 72,8 & 73,8 & 74,8 & 75,4 & 76,2 & 76,3 & 77,1 & 77,0 & 77,6 & 77,7 \\
\hline Gürcistan & 72,7 & 72,7 & 72,7 & 72,7 & 72,6 & 72,7 & 72,7 & 72,8 & 73,0 & 73,1 & 73,3 \\
\hline Hurvatistan & 75,8 & 75,7 & 75,9 & 76,2 & 76,5 & 76,8 & 76,9 & 77,1 & 77,5 & 77,3 & 78,0 \\
\hline Macaristan & 73,1 & 73,2 & 73,7 & 73,9 & 74,2 & 74,9 & 75,1 & 75,6 & 75,8 & 75,6 & 75,6 \\
\hline Kazakistan & 66,2 & 66,5 & 67,0 & 68,4 & 68,3 & 69,0 & 69,6 & 70,5 & 71,6 & 72,0 & 72,3 \\
\hline Kırgizistan & 67,7 & 67,9 & 68,5 & 69,1 & 69,3 & 69,6 & 70,0 & 70,2 & 70,4 & 70,7 & 71,0 \\
\hline Litvanya & 71,1 & 70,9 & 71,8 & 72,9 & 73,3 & 73,6 & 73,9 & 73,9 & 74,5 & 74,3 & 74,3 \\
\hline Letonya & 70,9 & 71,0 & 72,4 & 73,1 & 73,5 & 73,6 & 73,8 & 74,0 & 74,1 & 74,5 & 74,5 \\
\hline Moldova & 68,0 & 68,3 & 68,7 & 69,1 & 69,6 & 70,1 & 70,6 & 71,0 & 71,3 & 71,5 & 71,6 \\
\hline$\overline{\text { Karadağ }}$ & 73,8 & 74,1 & 74,5 & 74,9 & 75,3 & 75,7 & 76,1 & 76,4 & 76,7 & 76,9 & 77,1 \\
\hline Polonya & 75,1 & 75,2 & 75,5 & 75,7 & 76,2 & 76,7 & 76,7 & 77,0 & 77,6 & 77,5 & 77,5 \\
\hline Romanya & 72,2 & 72,6 & 72,6 & 73,3 & 73,5 & 74,4 & 74,4 & 75,1 & 75,0 & 75,0 & 75,0 \\
\hline Rusya & 66,7 & 67,6 & 67,9 & 68,7 & 68,8 & 69,7 & 70,1 & 70,6 & 70,7 & 71,2 & 71,6 \\
\hline Surbistan & 73,4 & 73,6 & 73,9 & 74,0 & 74,3 & 74,5 & 74,8 & 75,2 & 75,3 & 75,3 & 75,2 \\
\hline Slovakya & 74,2 & 74,2 & 74,7 & 74,9 & 75,1 & 76,0 & 76,1 & 76,4 & 76,8 & 76,6 & 76,6 \\
\hline Slovenya & 78,1 & 78,6 & 78,8 & 79,0 & 79,4 & 80,0 & 80,1 & 80,3 & 81,1 & 80,8 & 80,8 \\
\hline Tacikistan & 68,1 & 68,5 & 68,9 & 69,3 & 69,6 & 70,0 & 70,2 & 70,5 & 70,7 & 70,9 & 71,1 \\
\hline Türkiye & 72,9 & 73,2 & 73,5 & 73,9 & 74,2 & 74,4 & 74,7 & 75,0 & 75,2 & 75,5 & 75,8 \\
\hline Ukrayna & 68,1 & 68,2 & 68,3 & 69,2 & 70,3 & 70,8 & 70,9 & 71,2 & 71,2 & 71,2 & 71,5 \\
\hline Özbekistan & 68,7 & 69,0 & 69,3 & 69,7 & 70,0 & 70,3 & 70,6 & 70,8 & 71,0 & 71,2 & 71,3 \\
\hline
\end{tabular}

Kaynak: https://data.worldbank.org

Gelişmişliğin göstergesi olarak kabul edilen bu değişkenin 2006-2016 yıllarında almış olduğu değerler incelendiğinde yıllar itibariyle ülkelerin tamamında bu değerin arttığı görülmektedir (Bkz. Tablo 10 ). 2006 yılında en düşük doğumda yaşam beklentisi değeri 66,2, en yüksek değer 78,1 iken 2016 yılında doğumda yaşam beklentisinin en düşük değeri 71,0, en yüksek değeri ise 80,8 olmuştur. 2016 yılı itibariyle bu değerin en yüksek olduğu ülke 80,8 ile Slovenya'dır. Slovenya'yı 78,3 ile Arnavutluk ve Çek Cumhuriyeti, 78 ile Hırvatistan takip etmektedir. 
Doğumda yaşam beklentisinin en az olduğu ülke ise 71 ile Kırgızistan'dır. Türkiye'de ise bu değer 75,8 olup, diğer ülkelerle karşılaştırıldığında onuncu sırada yer aldığı görülmektedir.

\section{Ortaöğretime Katılma Oranı}

Bilgi ekonomisinde bir diğer önemli gösterge eğitim istatistikleridir. Ortaöğretim eğitim seviyesinin öğrencilerin mesleki alanlara yönlendirilmesi ve teknik elemanların yetiştirilmesi bakımından önemi büyüktür. Ortaöğretim okullaşma oranının yüksek olması kalifiye elaman yetiştirtilmesinde büyük bir etkiye sahiptir.

Beşeri sermayeye yapılan yatırımlar (eğitim-sağlık) yalnızca üretimle ilişkili değildir. Aynı zamanda bu yatırımların insanların yaşam kalitesini arttıran, sosyal ilişkileri geliştiren etkisi de söz konusudur (Karagül, 2003, s. 82).

Tablo 11. Ortaöğretime Katılma Oranı (2006-2016)

\begin{tabular}{|c|c|c|c|c|c|c|c|c|c|c|c|}
\hline Ülkeler & 2006 & 2007 & 2008 & 2009 & 2010 & 2011 & 2012 & 2013 & 2014 & 2015 & 2016 \\
\hline Arnavutluk & 79,6 & 82,7 & 84,6 & 86,2 & 88,6 & 90,2 & 92,6 & 95,8 & 96,3 & 95,8 & 95,0 \\
\hline Ermenistan & 94,9 & 96,4 & 95,0 & 100,1 & 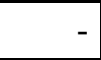 & 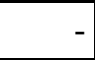 & - & 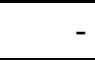 & - & 86,0 & - \\
\hline Bulgaristan & 89,7 & 90,2 & 89,4 & 88,7 & 90,2 & 93,7 & 94,7 & 101,4 & 104,2 & 102,3 & 99,9 \\
\hline Bosna Hersek & - & & - & & - & & & & - & & - \\
\hline Belarus & - & - & 111,2 & 110,1 & 107,6 & 106,7 & 106,5 & 104,7 & 104,8 & 104,8 & 104,4 \\
\hline Çek Cum. & 96,0 & 95,0 & 94,2 & 93,9 & 94,7 & 95,8 & 96,8 & 104,0 & 104,6 & 105,0 & - \\
\hline Estonya & 103,1 & 103,2 & 102,3 & 102,8 & 105,3 & 107,4 & 107,7 & 108,0 & 108,2 & 110,9 & - \\
\hline Gürcistan & 81,8 & 87,8 & 88,1 & 85,5 & - & - & - & 96,5 & 98,5 & 101,8 & 104,3 \\
\hline Hurvatistan & 94,9 & 96,6 & 98,4 & 99,9 & 99,9 & 99,2 & 99,1 & 99,6 & 98,7 & 98,2 & 97,8 \\
\hline Macaristan & 96,1 & 96,2 & 96,0 & 96,2 & 97,1 & 96,8 & 98,0 & 104,7 & 104,2 & 103,0 & 102,3 \\
\hline Kazakistan & 98,7 & - & - & - & 97,4 & 99,0 & 101,3 & 102,0 & 105,8 & 109,4 & 112,4 \\
\hline Kırgizistan & 86,5 & 86,2 & - & 86,7 & 87,5 & 87,5 & 88,6 & 89,6 & 92,1 & 93,3 & 97,6 \\
\hline Litvanya & 102,6 & 102,0 & 101,5 & 100,9 & 101,2 & 101,1 & 100,8 & 103,6 & 103,6 & 103,6 & 103,2 \\
\hline Letonya & 99,3 & 100,8 & 101,3 & 94,8 & 95,8 & 97,1 & 97,9 & 108,6 & 111,1 & 112,2 & - \\
\hline Moldova & 89,3 & 88,6 & 88,2 & 88,6 & 88,0 & 87,7 & 88,2 & 88,3 & 87,3 & 86,1 & - \\
\hline Karadağ & 95,6 & 95,8 & 95,4 & 97,5 & 100,4 & 93,4 & 93,1 & & - & 92,7 & 90,5 \\
\hline Polonya & 98,7 & 98,1 & 97,2 & 96,3 & 96,0 & 95,9 & 96,1 & 106,9 & 106,1 & 106,6 & 107,1 \\
\hline Romanya & 85,0 & 88,3 & 93,5 & 95,3 & 97,2 & 97,4 & 96,2 & 95,1 & 92,7 & 90,9 & 88,9 \\
\hline Rusya & 82,7 & 83,1 & 83,3 & 85,0 & - & 92,0 & 96,2 & 98,8 & 100,5 & 104,4 & 104,8 \\
\hline Surbistan & 89,0 & 89,5 & 90,5 & 91,5 & 91,4 & 93,6 & 94,2 & 94,4 & 94,3 & 96,7 & 96,2 \\
\hline Slovakya & 92,7 & 92,3 & 91,7 & 91,7 & 92,3 & 92,6 & 92,6 & 90,8 & 90,7 & 91,0 & - \\
\hline Slovenya & 96,8 & 98,5 & 98,6 & 98,5 & 98,7 & 98,6 & 98,0 & 110,6 & 110,0 & 109,8 & - \\
\hline Tacikistan & 82,0 & 82,8 & 83,3 & 83,6 & 84,1 & 85,0 & 86,2 & 87,4 & - & - & - \\
\hline Türkiye & 87,9 & 90,3 & 88,5 & 80,0 & 84,3 & 88,3 & 85,2 & 100,6 & 103,0 & 103,1 & - \\
\hline Ukrayna & 96,8 & 96,7 & 96,1 & 95,3 & 95,5 & 93,5 & 96,7 & 97,0 & 96,8 & - & - \\
\hline Özbekistan & 88,3 & 89,4 & 88,0 & 89,2 & 89,6 & 89,9 & 91,8 & 91,5 & 91,7 & 91,6 & 92,4 \\
\hline
\end{tabular}

Kaynak: https://data.worldbank.org 
2006-2016 dönemindeki okullaşma oranlarının gösterildiği Tablo 11'de değerlerin yıllar itibariyle arttığı görülmektedir. Ulaşılabilir verilerin daha çok olduğu 2015 yılı için bir değerlendirme yapıldığında ortaöğretim okullaşma oranı en düşük \%86,0 ile Ermenistan'da, en yüksek ise \%112,2 ile Letonya'da olmuştur. Türkiye'de ise ortaöğretime katılma oranı \%103,1 olup gruptaki diğer ülkelerle karşılaştırıldığında onuncu sırada yer aldığı görülmektedir.

\section{Yükseköğretime Katılma Oranı}

Yükseköğretim eğitim sisteminde önemli bir etkiye sahiptir. Bilgi ekonomisinde önemli yeri olan Ar-Ge personeli, yükseköğretimin çıktısı olup teknoloji geliştiren yeteneğin belirleyicisi pozisyonundadır (Kaynak, 2008, s. 91). Yüksek teknolojinin söz konusu olduğu savunma sanayi, uzay teknolojileri sahasında, ilaç sanayi, elektrik-elektronik ürün gruplarının üretildiği alanlarda daha çok nitelikli işgücünün tercih edildiği görülmektedir.

Tablo 12. Yükseköğretime Katılma Oranı (2006-2016)

\begin{tabular}{|c|c|c|c|c|c|c|c|c|c|c|c|}
\hline Ülkeler & 2006 & 2007 & 2008 & 2009 & 2010 & 2011 & 2012 & 2013 & 2014 & 2015 & 2016 \\
\hline Arnavutluk & 26,8 & 30,9 & 32,3 & 33,6 & 44,9 & 50,2 & 61,4 & 68,1 & 70,3 & 66,4 & 61,2 \\
\hline Ermenistan & 43,1 & 45,9 & 48,5 & 51,3 & 53,0 & 53,3 & 46,2 & 45,7 & 47,1 & 46,5 & 51,1 \\
\hline Bulgaristan & 47,2 & 50,6 & 51,9 & 54,2 & 57,8 & 59,0 & 61,3 & 64,2 & 67,6 & 70,3 & 71,2 \\
\hline Bosna Hersek & - & - & - & - & - & - & - & - & - & - & - \\
\hline Belarus & 69,2 & 71,2 & 70,7 & 74,0 & 79,1 & 85,6 & 91,3 & 92,5 & 90,2 & 88,2 & 87,0 \\
\hline Çek Cum. & 50,1 & 54,2 & 58,1 & 61,1 & 63,9 & 65,6 & 65,7 & 65,1 & 65,6 & 64,5 & - \\
\hline Estonya & 67,9 & 67,7 & 66,5 & 66,7 & 68,2 & 70,4 & 72,3 & 73,8 & 73,2 & 72,0 & - \\
\hline Gürcistan & 37,4 & 36,6 & 34,2 & 25,7 & 29,2 & 31,4 & 29,7 & 35,6 & 40,6 & 45,6 & 51,9 \\
\hline Hurvatistan & 45,6 & 47,2 & 49,2 & 48,8 & 54,0 & 57,2 & 60,4 & 65,3 & 67,6 & 67,0 & 67,5 \\
\hline Macaristan & 67,5 & 68,3 & 66,5 & 64,6 & 63,7 & 62,6 & 61,5 & 57,0 & 52,0 & 48,9 & 48,0 \\
\hline Kazakistan & 57,6 & - & - & - & 45,7 & 48,1 & 51,0 & 49,8 & 48,2 & 45,8 & 46,1 \\
\hline Kırgızistan & 43,6 & 42,9 & 46,7 & 44,3 & 42,1 & 41,3 & 43,9 & 47,6 & 46,3 & 47,3 & 45,9 \\
\hline Litvanya & 81,2 & 82,2 & 85,0 & 88,5 & 85,7 & 80,8 & 77,1 & 71,9 & 68,5 & 66,9 & 66,0 \\
\hline Letonya & 75,0 & 73,9 & 73,0 & 72,6 & 66,9 & 64,2 & 63,2 & 65,5 & 66,4 & 68,2 & - \\
\hline Moldova & 39,4 & 41,2 & 40,0 & 38,3 & 38,1 & 39,4 & 40,1 & 41,3 & 41,5 & 41,2 & - \\
\hline Karadağ & 25,9 & 33,3 & 41,0 & 49,2 & 52,2 & - & - & - & - & - & 56,9 \\
\hline Polonya & 65,4 & 67,2 & 70,3 & 72,4 & 74,8 & 74,7 & 74,0 & 71,8 & 68,3 & 66,7 & 66,6 \\
\hline Romanya & 51,6 & 57,9 & 66,1 & 69,6 & 65,3 & 59,5 & 50,7 & 47,6 & 47,5 & 46,8 & 48,0 \\
\hline Rusya & 72,8 & 74,1 & 75,0 & 75,4 & - & 76,5 & 76,1 & 78,1 & 78,7 & 80,5 & 81,8 \\
\hline Sirbistan & 46,8 & 48,0 & 48,7 & 49,8 & 49,1 & 51,6 & 53,5 & 56,4 & 58,1 & 58,3 & 62,1 \\
\hline Slovakya & 44,8 & 50,2 & 53,8 & 56,0 & 57,1 & 56,2 & 56,1 & 54,4 & 52,7 & - & - \\
\hline Slovenya & 82,6 & 84,6 & 85,5 & 86,4 & 89,1 & 85,9 & 86,9 & 85,1 & 82,1 & 80,0 & - \\
\hline Tacikistan & 22,0 & 22,8 & 23,2 & 22,8 & 22,9 & 22,2 & 22,6 & 22,8 & 24,5 & 26,3 & 28,8 \\
\hline Türkiye & 36,9 & 38,8 & 40,2 & 46,5 & 56,4 & 61,1 & 69,8 & 79,6 & 87,0 & 95,4 & - \\
\hline Ukrayna & 75,4 & 78,9 & 81,2 & 81,9 & 80,1 & 82,2 & 81,9 & 80,6 & 83,4 & - & - \\
\hline Özbekistan & 10,3 & 10,2 & 10,2 & 10,0 & 9,4 & 8,8 & 8,0 & 8,1 & 8,1 & 8,2 & 8,4 \\
\hline
\end{tabular}

Kaynak: https://data.worldbank.org 
Ulaşılabilir veriler çerçevesinde yukarıdaki tablo incelendiğinde 2006-2016 yıları arasında yükseköğretime katılma oranı; Macaristan, Kazakistan, Litvanya, Letonya, Romanya ve Özbekistan'da düşerken tablodaki diğer ülkelerde ciddi oranda arttığı görülmektedir (Bkz Tablo 12). 2015 yılı rakamlarına göre bu düzeyde okullaşma oranının en yüksek değeri $\% 95,4$ ile Türkiye'ye aitken, bu ülkeyi \%88,2 ile Belarus ve \%80,5 ile Rusya takip etmektedir. Yükseköğretim okullaşma oranının en düşük olduğu ülke ise \%8,4 ile Özbekistan'dır.

\section{İnovasyon Sistemi}

\section{Yüksek Teknoloji ìnracatı}

Ülkeler Ar-Ge faaliyetleri sonucunda yarattıkları yenilikleri sadece iç pazara sunmamakta aynı zamanda bu yenilikleri ihraç da etmektedir. İhracat daha geniş pazara hitap edilmesine olanak sağlamakta bu durum ise Ar-Ge'ye yapılan yatırımların birim maliyetlerinin azaltmakta ve yeni yeniliklerin yapılması için teşvik etmektedir. Ayrıca yenilik yaratan firmalar belli süreler dahilinde tekel gücü kazanmaktadır (Özer ve Çiftçi, 2009, s.49).

Tablo 13. Yüksek Teknoloji İhracatı(Mamul Mal İhracatının Yüzdesi, 2006-2016)

\begin{tabular}{|l|r|r|r|r|r|r|r|r|r|r|r|}
\hline Ülke adı & $\mathbf{2 0 0 6}$ & $\mathbf{2 0 0 7}$ & $\mathbf{2 0 0 8}$ & $\mathbf{2 0 0 9}$ & $\mathbf{2 0 1 0}$ & $\mathbf{2 0 1 1}$ & $\mathbf{2 0 1 2}$ & $\mathbf{2 0 1 3}$ & $\mathbf{2 0 1 4}$ & $\mathbf{2 0 1 5}$ & $\mathbf{2 0 1 6}$ \\
\hline Arnavutluk & 6,2 & 1,3 & 3,5 & 0,8 & 0,9 & 0,5 & 0,4 & 0,5 & 0,1 & 1,5 & 0,6 \\
\hline Ermenistan & 1,1 & 0,9 & 1,4 & 2,2 & 1,8 & 2,6 & 2,6 & 2,9 & 2,7 & 5,3 & 5,9 \\
\hline Bulgaristan & 6,1 & 6,0 & 6,6 & 8,2 & 7,9 & 7,5 & 7,7 & 8,0 & 6,9 & 7,6 & 8,0 \\
\hline Bosna Hersek & 2,2 & 2,1 & 4,1 & 3,3 & 2,6 & 3,0 & 2,5 & 2,3 & 2,4 & 2,8 & 2,6 \\
\hline Belarus & 2,8 & 2,8 & 2,4 & 3,1 & 3,0 & 2,6 & 2,9 & 4,4 & 3,9 & 4,3 & 4,7 \\
\hline Çek Cum. & 14,3 & 13,2 & 13,6 & 14,6 & 15,3 & 16,3 & 16,1 & 14,8 & 14,9 & 14,9 & 13,9 \\
\hline Estonya & 12,6 & 5,8 & 5,4 & 5,7 & 9,3 & 13,4 & 10,8 & 10,5 & 11,4 & 11,4 & 10,3 \\
\hline Gürcistan & 16,5 & 7,5 & 2,7 & 3,9 & 1,9 & 1,3 & 2,4 & 2,4 & 3,0 & 5,6 & 3,9 \\
\hline Hurvatistan & 9,9 & 8,2 & 8,4 & 9,8 & 9,2 & 7,6 & 9,9 & 10,2 & 8,4 & 9,0 & 11,6 \\
\hline Macaristan & 24,1 & 23,8 & 23,3 & 24,9 & 24,1 & 22,7 & 17,9 & 16,3 & 13,7 & - & 14,0 \\
\hline Kazakistan & 20,9 & 21,4 & 21,9 & 29,9 & 34,2 & 24,7 & 30,0 & 36,7 & 37,2 & 41,2 & 30,4 \\
\hline Kurgizistan & 2,9 & 2,2 & 3,0 & 4,9 & 1,0 & 3,0 & 4,6 & 5,3 & - & 11,9 & 18,5 \\
\hline Litvanya & 8,1 & 10,8 & 11,1 & 10,0 & 10,6 & 10,2 & 10,4 & 10,3 & 10,1 & 11,9 & 11,7 \\
\hline Letonya & 6,8 & 6,9 & 7,0 & 7,8 & 7,6 & 8,2 & 9,8 & 13,0 & 15,0 & - & 12,5 \\
\hline Moldova & 4,8 & 5,1 & 4,2 & 4,6 & 8,3 & 6,3 & 4,8 & 2,4 & 4,8 & 4,0 & 3,1 \\
\hline Karadağ & - & - & - & - & - & - & - & - & - & - & - \\
\hline Polonya & 3,7 & 3,0 & 4,3 & 6,1 & 6,7 & 5,9 & 7,0 & 7,8 & 8,7 & 8,8 & 8,5 \\
\hline Romanya & 4,8 & 3,5 & 6,7 & 9,1 & 10,9 & 10,2 & 6,4 & 5,7 & 6,4 & 7,5 & 8,5 \\
\hline Rusya & 7,8 & 6,9 & 6,5 & 9,2 & 9,1 & 8,0 & 8,4 & 10,0 & 11,5 & 13,8 & 10,7 \\
\hline Sirbistan & 3,6 & 3,6 & - & - & - & - & - & - & - & - & - \\
\hline Slovakya & 6,7 & 5,4 & 5,3 & 5,7 & 6,8 & 7,1 & 9,2 & 10,3 & 10,2 & 10,3 & 9,8 \\
\hline Slovenya & 5,5 & 5,0 & 5,8 & 6,5 & 5,7 & 5,8 & 6,2 & 6,2 & 5,8 & 6,4 & 7,4 \\
\hline Tacikistan & - & - & - & - & - & - & - & - & - & - & - \\
\hline Türkiye & 1,9 & 1,9 & 1,6 & 1,7 & 1,9 & 1,8 & 1,8 & 1,9 & 1,9 & 2,2 & 2,0 \\
\hline Ukrayna & 3,4 & 3,7 & 3,3 & 5,6 & 4,3 & 4,4 & 6,3 & 5,9 & 6,5 & 7,3 & - \\
\hline Özbekistan & - & - & - & - & - & - & - & - & - & - & - \\
\hline & & & & & & & & & \\
\hline
\end{tabular}

Kaynak: https://data.worldbank.org 
2006-2016 mamul mal ihracatının yüzdesi olarak verilen yüksek teknoloji ihracatına ilişkin rakamlar Tablo 13'te gösterilmiştir. İhracat rakamlarının yıllar itibariyle inişli çıkışlı bir seyir izlediği görülmektedir. Yine burada da gerek ülke içinde gerekse küresel etkilerden kaynaklı sorunlar ihracatı olumsuz yönde etkilediği anlaşılmaktadır. 2016 yılında en yüksek oranda ileri teknoloji ihracatı yapan ülke \%30,4 ile Kazakistan, en düşük oranda ihracat yapan ülke ise \%0,6 oranında Arnavutluk olmuştur. Türkiye' deki Yüksek teknoloji ihracatının payı \%2,0 olup gruptaki verileri olan diğer ülkelerle karşılaştırıldığında son sırada yer almaktadır.

\section{Patent Sayısı}

Patent, bilgi, icat ve yeniliğin ticarileştirilmesinde ve buradan hareketle piyasa ürünü haline getirilmesinde önemli bir araç olup ilgili ülkenin veya firmanın teknoloji yeteneğini gösteren önemli bir ölçüttür. Teknolojik yenilik faaliyetlerinde Ar-Ge harcaması bir girdi iken, bu faaliyetler sonucunda alınan patent sayısı bir sonuç (çıktı) olarak düşünülebilir.

Tablo 14. Toplam Patent Sayıs

\begin{tabular}{|c|c|c|c|c|c|c|c|c|c|c|c|}
\hline Ülke adı & 2006 & 2007 & 2008 & 2009 & 2010 & 2011 & 2012 & 2013 & 2014 & 2015 & 2016 \\
\hline Arnavutluk & - & - & - & 361 & - & 11 & - & 4 & 13 & 19 & 25 \\
\hline Ermenistan & 193 & 140 & 230 & 127 & 142 & 140 & 141 & 131 & 123 & 115 & 126 \\
\hline Bulgaristan & 291 & 239 & 271 & 266 & 260 & 283 & 259 & 297 & 234 & 291 & 241 \\
\hline Bosna Hersek & 217 & - & 71 & - & 65 & 55 & 16 & 29 & 43 & - & 66 \\
\hline Belarus & 1.525 & 1.662 & 1.730 & 1.926 & 1.933 & 1.871 & 1.871 & 1.634 & 757 & 691 & 521 \\
\hline Çek Cum. & 836 & 908 & 854 & 881 & 982 & 880 & 1.017 & 1.081 & 972 & 952 & 839 \\
\hline Estonya & 45 & 63 & 72 & 96 & 97 & 77 & 25 & 42 & 50 & 36 & 30 \\
\hline Gürcistan & 535 & 564 & 463 & 474 & 362 & 398 & 372 & 333 & 297 & 271 & 274 \\
\hline Hırvatistan & 436 & 437 & 401 & 318 & 278 & 251 & 249 & 253 & 200 & 186 & 188 \\
\hline Macaristan & 924 & 791 & 772 & 787 & 696 & 698 & 758 & 708 & 619 & 633 & 665 \\
\hline Kazakistan & 1.557 & 1.827 & 1.672 & 1.827 & 1.964 & 1.732 & - & 2.202 & 2.013 & 1.503 & 1.224 \\
\hline Kırgızistan & 0 & 158 & 138 & 149 & 140 & 129 & 111 & 114 & 139 & 126 & 89 \\
\hline Litvanya & 99 & 82 & 105 & 107 & 114 & 108 & 124 & 137 & 165 & 119 & 153 \\
\hline Letonya & 151 & 147 & 215 & 243 & 185 & 183 & 205 & 233 & 107 & 137 & 113 \\
\hline Moldova & 312 & 347 & 295 & 139 & 150 & 108 & 115 & 96 & 139 & 124 & 155 \\
\hline Karadağ & - & - & 917 & - & 159 & 103 & 78 & 23 & 13 & 23 & 10 \\
\hline Polonya & 2.812 & 2.753 & 2.778 & 3.140 & 3.430 & 4.123 & 4.657 & 4.411 & 4.096 & 4.815 & 4.396 \\
\hline Romanya & 876 & 886 & 1.031 & 1.091 & 1.418 & 1.463 & 1.077 & 1.046 & 1.036 & 1.053 & 1.063 \\
\hline Rusya & 37.691 & 39.439 & 41.849 & 38.564 & 42.500 & 41.414 & 44.211 & 44.914 & 40.308 & 45.517 & 41.587 \\
\hline Sirbistan & 705 & 516 & 623 & 359 & 329 & 229 & 224 & 221 & 212 & 191 & 213 \\
\hline Slovakya & 283 & 345 & 242 & 239 & 282 & 257 & 203 & 210 & 234 & 256 & 235 \\
\hline Slovenya & 299 & 346 & 307 & 385 & 453 & 481 & - & - & - & - & - \\
\hline Tacikistan & 26 & - & - & 12 & 10 & 5 & 6 & 4 & - & 1 & - \\
\hline Türkiye & 1.232 & 2.021 & 2.397 & 2.732 & 3.357 & 4.113 & 4.666 & 4.661 & 5.097 & 5.841 & 6.848 \\
\hline Ukrayna & 5.890 & 6.163 & 5.697 & 4.814 & 5.312 & 5.253 & 4.955 & 5.412 & 4.813 & 4.497 & 4.095 \\
\hline Özbekistan & 509 & 522 & 448 & 412 & 632 & 556 & 510 & 557 & 568 & 507 & 555 \\
\hline
\end{tabular}

Kaynak: https://data.worldbank.org 
Tablo 14’te 2006-2016 döneminde alınan toplam patent sayılarına ilişkin veriler yer almaktadır. Tablo incelendiğinde yıllar itibariyle patent sayısında yıllar itibariyle artan ve azalan değerler olduğu görülmektedir. 2016 yılında patent sayısının en düşük olduğu ülke Karadağ (10) iken patent sayısının en yüksek olduğu ülke Rusya olmuştur (41.587). Rusya’yı 6.848 ile Türkiye, 4.396 ile Polonya takip etmektedir. Patent sayısı bakımından Türkiye’nin yer aldığı gruptaki diğer ülkelerle karşılaştırıldığında ikinci sırada yer aldığı görülmektedir.

\section{Ar-Ge Harcaması}

Ar-Ge "yenilik, buluş, ürün geliştirme ve süreç iyileştirme ile birlikte, mevcut işi yenileme, genişletme ya da yeni işler yaratma potansiyeline sahip ve teknolojiyle ilgili her türlü faaliyeti” kapsamaktadır (Çeken, 2016, s.103).

Ar-Ge faaliyetlerinin en önemli çıktısı olarak kabul edilen yeniliğin firmaların başarısı ve rekabeti açısından önemi büyüktür. Yeniliklerin yetersiz oluşu firmanın performansının düşmesine ve dolaysıyla firmanın piyasadaki rekabet gücünü kaybetmesine sebebiyet vermektedir (Auken vd., 2008, s. 51).

Tablo 15. Araştırma ve Geliştirme Harcamaları (GSYİH’ nın Yüzdesi, 2006-2015)

\begin{tabular}{|l|r|r|r|r|r|r|r|r|r|r|}
\hline Ülke adı & $\mathbf{2 0 0 6}$ & $\mathbf{2 0 0 7}$ & $\mathbf{2 0 0 8}$ & $\mathbf{2 0 0 9}$ & $\mathbf{2 0 1 0}$ & $\mathbf{2 0 1 1}$ & $\mathbf{2 0 1 2}$ & $\mathbf{2 0 1 3}$ & $\mathbf{2 0 1 4}$ & $\mathbf{2 0 1 5}$ \\
\hline Arnavutluk & - & 0,1 & 0,2 & - & - & - & - & - & - & - \\
\hline Ermenistan & 0,2 & 0,2 & 0,2 & 0,3 & 0,2 & 0,3 & 0,2 & 0,2 & 0,2 & 0,3 \\
\hline Bulgaristan & 0,4 & 0,4 & 0,4 & 0,5 & 0,6 & 0,5 & 0,6 & 0,6 & 0,8 & 1,0 \\
\hline Bosna Hersek & 0,0 & 0,0 & 0,0 & 0,0 & - & - & 0,3 & 0,3 & 0,3 & 0,2 \\
\hline Belarus & 0,7 & 1,0 & 0,7 & 0,6 & 0,7 & 0,7 & 0,7 & 0,7 & 0,5 & 0,5 \\
\hline Çek Cum. & 1,2 & 1,3 & 1,2 & 1,3 & 1,3 & 1,6 & 1,8 & 1,9 & 2,0 & 1,9 \\
\hline Estonya & 1,1 & 1,1 & 1,3 & 1,4 & 1,6 & 2,3 & 2,1 & 1,7 & 1,5 & 1,5 \\
\hline Gürcistan & - & - & - & - & - & - & - & 0,1 & 0,2 & 0,3 \\
\hline Hırvatistan & 0,7 & 0,8 & 0,9 & 0,8 & 0,7 & 0,8 & 0,8 & 0,8 & 0,8 & 0,9 \\
\hline Macaristan & 1,0 & 1,0 & 1,0 & 1,1 & 1,1 & 1,2 & 1,3 & 1,4 & 1,4 & 1,4 \\
\hline Kazakistan & 0,2 & 0,2 & 0,2 & 0,2 & 0,2 & 0,2 & 0,2 & 0,2 & 0,2 & 0,2 \\
\hline Kirgizistan & 0,2 & 0,2 & 0,2 & 0,2 & 0,2 & 0,2 & 0,2 & 0,1 & 0,1 & 0,1 \\
\hline Litvanya & 0,8 & 0,8 & 0,8 & 0,8 & 0,8 & 0,9 & 0,9 & 1,0 & 1,0 & 1,0 \\
\hline Letonya & 0,7 & 0,6 & 0,6 & 0,5 & 0,6 & 0,7 & 0,7 & 0,6 & 0,7 & 0,6 \\
\hline Moldova & 0,4 & 0,5 & 0,5 & 0,5 & 0,4 & 0,4 & 0,4 & 0,4 & 0,4 & 0,4 \\
\hline Karadağ & 1,2 & 1,1 & - & - & - & 0,3 & - & 0,4 & 0,4 & 0,4 \\
\hline Polonya & 0,6 & 0,6 & 0,6 & 0,7 & 0,7 & 0,7 & 0,9 & 0,9 & 0,9 & 1,0 \\
\hline Romanya & 0,5 & 0,5 & 0,6 & 0,5 & 0,5 & 0,5 & 0,5 & 0,4 & 0,4 & 0,5 \\
\hline Rusya & 1,1 & 1,1 & 1,0 & 1,3 & 1,1 & 1,0 & 1,0 & 1,1 & 1,1 & 1,1 \\
\hline Sirbistan & 0,5 & 0,6 & 0,7 & 0,9 & 0,7 & 0,7 & 0,9 & 0,7 & 0,8 & 0,9 \\
\hline Slovakya & 0,5 & 0,4 & 0,5 & 0,5 & 0,6 & 0,7 & 0,8 & 0,8 & 0,9 & 1,2 \\
\hline Slovenya & 1,5 & 1,4 & 1,6 & 1,8 & 2,1 & 2,4 & 2,6 & 2,6 & 2,4 & 2,2 \\
\hline Tacikistan & 0,1 & 0,1 & 0,1 & 0,1 & 0,1 & 0,1 & 0,1 & 0,1 & 0,1 & 0,1 \\
\hline Türkiye & 0,6 & 0,7 & 0,7 & 0,8 & 0,8 & 0,9 & 0,9 & 0,9 & 1,0 & 1,1 \\
\hline Ukrayna & 0,9 & 0,9 & 0,8 & 0,9 & 0,8 & 0,7 & 0,8 & 0,8 & 0,6 & 0,6 \\
\hline Özbekistan & 0,2 & 0,2 & 0,2 & 0,2 & 0,2 & 0,2 & 0,2 & 0,2 & 0,2 & 0,2 \\
\hline
\end{tabular}

Kaynak: https://data.worldbank.org 
Ar-Ge harcamaları, ülkelerin teknoloji ve bilimde hangi düzeyde olduğunu gösteren önemli bir ölçüttür. Buradan hareketle Tablo 15'e bakıldığında GSYİH içerisinde Ar-Ge harcamalarının yıllar itibariyle arttığı görülmektedir. 2015 yılında en düşük Ar-Ge harcaması \% 0,1 oranında Kırgızistan, Tacikistan ve Türkiye'de yapılırken, en yüksek oranda Ar-Ge harcaması \% 2,2 oranında Slovenya'da yapılmıştır. Türkiye'de ise 2015 yılında GSYİH içinde Ar-Ge faaliyetlerinin payı \% 1,1'dir. Bu oran gruptaki diğer ülkelerle karşılaştırıldığında altıncı sırada olduğunu göstermektedir.

\section{Ar-Ge Araştırmacıları}

Keesing, Kenen, Leontief, Irving Kravisin geliştirdiği nitelikli işgücü teorisi, sanayileşmiş ülkelerdeki dış ticaretin büyük bölümünün altında yatan nedenin ülkeler arasındaki nitelikli iş gücü farklılığından kaynaklandığına işaret etmektedir. Belli bir nitelikteki iş gücü açısından zengin ülke, üretimini bu faktöre bağlı olan mallarda uzmanlaşmaya giderek daha çok bu malların ticaretini yapmaktadır (Dura, 2009).

Tablo 16. Ar-Ge Araştırmacıları (Milyon Kişi)

\begin{tabular}{|l|r|r|r|r|r|r|r|r|r|r|}
\hline Ülke adı & $\mathbf{2 0 0 6}$ & $\mathbf{2 0 0 7}$ & $\mathbf{2 0 0 8}$ & $\mathbf{2 0 0 9}$ & $\mathbf{2 0 1 0}$ & $\mathbf{2 0 1 1}$ & $\mathbf{2 0 1 2}$ & $\mathbf{2 0 1 3}$ & $\mathbf{2 0 1 4}$ & $\mathbf{2 0 1 5}$ \\
\hline Arnavutluk & - & - & 157 & - & - & - & - & - & - & - \\
\hline Ermenistan & - & - & - & - & - & - & - & - & - & - \\
\hline Bulgaristan & 1.356 & 1.480 & 1.515 & 1.604 & 1.482 & 1.618 & 1.547 & 1.693 & 1.833 & 1.989 \\
\hline Bosna Hersek & 175 & 194 & - & - & - & - & 151 & 217 & 267 & 329 \\
\hline Belarus & - & - & - & - & - & - & - & - & - & - \\
\hline Çek Cum. & 2.557 & 2.699 & 2.865 & 2.749 & 2.782 & 2.913 & 3.150 & 3.250 & 3.418 & 3.612 \\
\hline Estonya & 2.603 & 2.745 & 2.970 & 3.229 & 3.061 & 3.397 & 3.461 & 3.339 & 3.284 & 3.189 \\
\hline Gürcistan & - & - & - & - & - & - & - & 562 & 1.060 & 1.288 \\
\hline Hırvatistan & 1.323 & 1.407 & 1.542 & 1.601 & 1.646 & 1.592 & 1.560 & 1.529 & 1.437 & 1.502 \\
\hline Macaristan & 1.741 & 1.728 & 1.841 & 1.999 & 2.131 & 2.304 & 2.394 & 2.523 & 2.651 & 2.569 \\
\hline Kazakistan & - & 405 & 375 & 347 & 369 & 384 & 610 & 734 & - & - \\
\hline Kırgizistan & - & - & - & - & - & - & - & - & - & - \\
\hline Litvanya & 2.414 & 2.594 & 2.619 & 2.676 & 2.754 & 2.732 & 2.660 & 2.887 & 3.111 & 2.822 \\
\hline Letonya & 1.789 & 1.914 & 2.038 & 1.710 & 1.864 & 1.913 & 1.916 & 1.802 & 1.884 & 1.834 \\
\hline Moldova & 605 & 628 & 713 & 699 & 663 & 679 & 671 & 644 & 652 & 662 \\
\hline Karadağ & - & - & - & - & - & 652 & - & 647 & 673 & 836 \\
\hline Polonya & 1.548 & 1.595 & 1.604 & 1.585 & 1.672 & 1.662 & 1.735 & 1.851 & 2.036 & 2.139 \\
\hline Romanya & 897 & 896 & 935 & 940 & 974 & 800 & 903 & 938 & 922 & 895 \\
\hline Rusya & 3.240 & 3.276 & 3.153 & 3.090 & 3.088 & 3.125 & 3.094 & 3.073 & 3.102 & 3.131 \\
\hline Sirbistan & - & 1.196 & 1.360 & 1.429 & 1.515 & 1.624 & 1.643 & 1.727 & 1.831 & 2.071 \\
\hline Slovakya & 2.186 & 2.291 & 2.332 & 2.460 & 2.808 & 2.832 & 2.820 & 2.718 & 2.719 & 2.655 \\
\hline Slovenya & 2.920 & 3.098 & 3.463 & 3.645 & 3.753 & 4.261 & 4.307 & 4.217 & 4.150 & 3.821 \\
\hline Tacikistan & - & - & - & - & - & - & - & - & - & - \\
\hline Türkiye & 621 & 714 & 751 & 811 & 890 & 981 & 1.097 & 1.169 & 1.157 & - \\
\hline Ukrayna & 1.479 & 1.459 & 1.432 & 1.350 & 1.332 & 1.262 & 1.235 & 1.165 & 1.026 & 1.006 \\
\hline Özbekistan & 578 & 570 & 595 & 588 & 549 & 534 & 528 & 523 & 518 & 515 \\
\hline
\end{tabular}

Kaynak: https://data.worldbank.org 
Tablo 16 incelendiğinde 20006-2016 döneminde Ar-Ge araştırmacılarının sayısında bir artış söz konusudur. 2015 yılında en yüksek araştırmacı sayısına sahip ülke 3.821 kişi ile Slovenya'dır. Bu ülkeyi 3612 kişi ile Çek Cumhuriyeti, 3189 kişi ile de Estonya izlemektedir. En az Ar-Ge araştırmacısının olduğu ülke 329 kişi ile Bosna Hersek'tir. Türkiye de ise 2015 yılında 1.157 kişi Ar-Ge araştırmacısı olarak çalışmaktadır. Bu rakam Türkiye'nin gruptaki verisi olan diğer ülkelere göre on üçüncü sırada olduğunu göstermektedir.

\section{Bilimsel ve Teknik Makaleleri}

Aşağıdaki tabloda 2006-2016 yılları arasındaki bilimsel ve teknik dergi makalelerine ilişkin rakamlar yer almaktadır (Bkz. Tablo 17). Rakamlarda yıllar itibariyle azalışlar ve artışların olduğu görülmektedir. 2016 yılında en az makale Tacikistan'da (48 adet) yazılmış, en çok makale ise Rusya'da (59.134 adet) yazılmıştır. Rusya'yı 33.902 adet makale ile Türkiye ve 32.978 adet makale ile Polonya takip etmektedir.

Tablo 17. Bilimsel ve Teknik Makaleleri (2006-2016)

\begin{tabular}{|c|c|c|c|c|c|c|c|c|c|c|c|}
\hline Ülke adı & 2006 & 2007 & 2008 & 2009 & 2010 & 2011 & 2012 & 2013 & 2014 & 2015 & 2016 \\
\hline Arnavutluk & 33 & 40 & 52 & 77 & 141 & 165 & 214 & 360 & 361 & 269 & 191 \\
\hline Ermenistan & 360 & 401 & 395 & 447 & 494 & 619 & 551 & 552 & 559 & 531 & 521 \\
\hline Bulgaristan & 1.928 & 2.483 & 2.357 & 2.552 & 2.599 & 2.554 & 2.733 & 2.753 & 2.744 & 2.605 & 2.559 \\
\hline Bosna Hersek & 223 & 243 & 373 & 407 & 495 & 543 & 573 & 495 & 478 & 525 & 509 \\
\hline Belarus & 1.160 & 1.293 & 1.038 & 1.172 & 1.057 & 1.099 & 1.015 & 1.041 & 1.053 & 970 & 937 \\
\hline Çek Cum. & 8.839 & 9.988 & 10.649 & 11.198 & 12.674 & 13.545 & 13.949 & 14.402 & 15.675 & 16.873 & 15.963 \\
\hline Estonya & 854 & 1.015 & 1.118 & 1.128 & 1.407 & 1.382 & 1.475 & 1.506 & 1.675 & 1.604 & 1.482 \\
\hline Gürcistan & 358 & 307 & 350 & 407 & 346 & 463 & 441 & 473 & 486 & 492 & 579 \\
\hline Hurvatistan & 3.124 & 3.758 & 3.976 & 4.410 & 4.421 & 4.966 & 4.814 & 4.702 & 4.474 & 4.398 & 4.056 \\
\hline Macaristan & 5.530 & 5.885 & 6.409 & 6.030 & 5.871 & 6.419 & 6.571 & 6.468 & 6.859 & 6.566 & 6.208 \\
\hline Kazakistan & 215 & 214 & 227 & 270 & 324 & 383 & 479 & 1.015 & 1.066 & 1.259 & 1.564 \\
\hline Kırgizistan & 50 & 37 & 51 & 34 & 34 & 50 & 49 & 63 & 56 & 51 & 101 \\
\hline Litvanya & 1.677 & 1.579 & 2.493 & 2.265 & 2.346 & 2.457 & 2.311 & 2.319 & 2.472 & 2.461 & 2.181 \\
\hline Letonya & 367 & 474 & 585 & 682 & 767 & 1.274 & 1.194 & 1.235 & 1.162 & 1.476 & 1.257 \\
\hline Moldova & 144 & 147 & 165 & 199 & 172 & 203 & 231 & 231 & 239 & 194 & 295 \\
\hline Karadağ & - & 64 & 66 & 67 & 107 & 134 & 162 & 199 & 219 & 206 & 258 \\
\hline Polonya & 21.267 & 21.569 & 23.376 & 23.471 & 24.552 & 25.858 & 28.115 & 30.064 & 31.779 & 32.767 & 32.978 \\
\hline Romanya & 3.523 & 5.170 & 7.368 & 9.550 & 11.010 & 10.906 & 11.062 & 11.177 & 10.801 & 11.527 & 10.194 \\
\hline Rusya & 29.369 & 30.320 & 31.854 & 32.620 & 33.961 & 36.157 & 36.253 & 39.715 & 44.995 & 53.061 & 59.134 \\
\hline Sirbistan & - & 2.843 & 3.097 & 3.711 & 4.121 & 4.920 & 6.077 & 5.472 & 5.233 & 5.072 & 5.052 \\
\hline Slovakya & 2.644 & 2.800 & 3.333 & 3.164 & 3.638 & 3.900 & 4.262 & 4.617 & 5.136 & 5.206 & 5.359 \\
\hline Slovenya & 2.393 & 2.754 & 3.007 & 3.221 & 3.247 & 3.780 & 3.708 & 3.726 & 3.789 & 3.632 & 3.407 \\
\hline Tacikistan & 26 & 33 & 30 & 23 & 41 & 43 & 48 & 62 & 38 & 54 & 48 \\
\hline Türkiye & 19.547 & 21.523 & 21.735 & 24.447 & 25.584 & 26.808 & 28.501 & 31.147 & 31.674 & 33.113 & 33.902 \\
\hline Ukrayna & 5.296 & 5.489 & 5.907 & 5.653 & 6.074 & 6.400 & 6.716 & 7.450 & 7.417 & 7.455 & 7.375 \\
\hline Özbekistan & 291 & 347 & 301 & 336 & 389 & 379 & 325 & 353 & 332 & 288 & 357 \\
\hline
\end{tabular}

Kaynak: https://data.worldbank.org 
Türkiye'de de yıllar itibariyle makale sayısında artış olmuştur. 2006 yılındaki makale sayısı 19.547 iken bu rakam 2016 yılında 33.902 adete yükselmiştir. Bu da gruptaki diğer ülkelere göre Türkiye'nin ikinci sırada olduğunu yansıtmaktadır.

\section{Bilgi Altyapısı}

\section{Telefon Abonelikleri}

Bilgi ekonomisindeki gelişmeler yeni bilgi ve iletişim araçlarının ortaya çıkmasına neden olmuş, bunun sonucunda da bu araçların kullanıcı sayısı her geçen gün ciddi oranda artmıştır.

Bilgi paylaşılmasının hızlanmasına olanak tanıyan ve üretim maliyetlerinin düşmesinde etkili olan bilgi ekonomisi göstergelerden bir tanesi olan telefon aboneliklerine ilişkin veriler Tablo 18 'de gösterilmiştir.

Tablo 18. Sabit ve Mobil Telefon Abonelikleri (Her 100 Kişi, 2006-2016)

\begin{tabular}{|c|c|c|c|c|c|c|c|c|c|c|c|}
\hline Ülke adı & 2006 & 2007 & 2008 & 2009 & 2010 & 2011 & 2012 & 2013 & 2014 & 2015 & 2016 \\
\hline Arnavutluk & 71 & 87 & 74 & 95 & 103 & 118 & 131 & 136 & 123 & 124 & 124 \\
\hline Ermenistan & 63 & 85 & 71 & 97 & 155 & 132 & 136 & 136 & 139 & 138 & 136 \\
\hline Bulgaristan & 140 & 161 & 168 & 170 & 167 & 173 & 177 & 171 & 157 & 151 & 147 \\
\hline Bosna Hersek & 76 & 93 & 112 & 114 & 110 & 112 & 116 & 120 & 122 & 119 & 118 \\
\hline Belarus & 97 & 112 & 125 & 144 & 153 & 157 & 159 & 164 & 168 & 169 & 168 \\
\hline Çek Cum. & 149 & 151 & 156 & 149 & 145 & 145 & 148 & 148 & 150 & 135 & 134 \\
\hline Estonya & 156 & 162 & 158 & 155 & 160 & 172 & 185 & 178 & 175 & 174 & 173 \\
\hline Gürcistan & 51 & 72 & 78 & 81 & 120 & 138 & 145 & 153 & 163 & 165 & 162 \\
\hline Hurvatistan & 143 & 158 & 148 & 151 & 157 & 161 & 156 & 149 & 142 & 139 & 139 \\
\hline Macaristan & 133 & 143 & 153 & 149 & 151 & 148 & 147 & 148 & 150 & 152 & 153 \\
\hline Kazakistan & 68 & 98 & 115 & 129 & 143 & 177 & 205 & 202 & 188 & 172 & 164 \\
\hline Kırgızistan & 34 & 51 & 74 & 93 & 106 & 123 & 130 & 127 & 139 & 136 & 134 \\
\hline Litvanya & 167 & 175 & 181 & 180 & 181 & 183 & 187 & 173 & 164 & 162 & 163 \\
\hline Letonya & 128 & 130 & 133 & 134 & 134 & 135 & 150 & 146 & 138 & 148 & 153 \\
\hline Moldova & 57 & 72 & 86 & 80 & 91 & 108 & 118 & 121 & 122 & 121 & 122 \\
\hline Karadă & 131 & 174 & 214 & 235 & 215 & 213 & 185 & 185 & 188 & 185 & 189 \\
\hline Polonya & 126 & 135 & 139 & 139 & 143 & 149 & 157 & 170 & 174 & 166 & 160 \\
\hline Romanya & 95 & 118 & 140 & 145 & 141 & 139 & 136 & 138 & 138 & 138 & 137 \\
\hline Rusya & 136 & 151 & 171 & 193 & 197 & 173 & 175 & 180 & 180 & 183 & 182 \\
\hline Sirbistan & 126 & 155 & 173 & 178 & 179 & 183 & 169 & 172 & 173 & 170 & 167 \\
\hline Slovakya & 112 & 137 & 126,1 & 124 & 130 & 130 & 131 & 132 & 134 & 139 & 144 \\
\hline Slovenya & 142 & 146 & 150 & 149 & 148 & 149 & 149 & 149 & 150 & 150 & 150 \\
\hline Tacikistan & 31 & 34 & 54 & 70 & 83 & 86 & 87 & 97 & 101 & 105 & 113 \\
\hline Türkiye & 104 & 115 & 118 & 111 & 108 & 110 & 109 & 110 & 110 & 109 & 108 \\
\hline Ukrayna & 132 & 147 & 149 & 148 & 146 & 150 & 158 & 165 & 169 & 166 & 155 \\
\hline Özbekistan & 16 & 28 & 51 & 65 & 80 & 94 & 75 & 78 & 79 & 79 & 85 \\
\hline
\end{tabular}

Kaynak: https://data.worldbank.org 
Her 100 kişi için 2006-2016 dönemindeki veriler incelendiğinde telefon aboneliklerinde hızlı bir atış olduğu tablodan açıkça görülmektedir (Bkz. Tablo 18). Telefon aboneliğindeki en büyük artış 189 kişi ile Karadağ’da gerçekleşmiştir. Karadağ’ 182 ile Rusya ve 173 ile Estonya takip etmektedir. Telefon aboneliğindeki en düşük orandaki artış 85 ile Özbekistan'da olmuştur. Türkiye'de ise 2016 yılı itibariyle telefon aboneliklerinde artış 108 oranında gerçekleşmiştir.

\section{internet Kullanıcıları}

Bilgi ekonomisindeki gelişmelerle birlikte iktisadi faaliyetlerin büyük bir kısmı internet ortamına gerçekleşmektedir. Ortak ürün tasarlama ve geliştirme, para transferi, mal veya hizmet alım-satımı, sözleşme, ihale gibi çeşitli işlemler teknolojiler sayesinde internet ortamında kolayca yapılabilmektedir Gürdal, 2004, s. 54). İnternet ortamı önceki dönemlerde telefon ve televizyonların yaptığı bilgi edinme işlemini çok kolay bir şekilde yapılmasına imkan vermiştir. Böylelikle hem bilgi edinmenin maliyetini azaltmış hem de zamanda tasarruf edilmesine neden olmuştur (Cecchetti, 2002, s. 3).

Tablo 19. İnternet Kullanıcıları (Nüfusun \%'si, 2006-2016)

\begin{tabular}{|c|c|c|c|c|c|c|c|c|c|c|c|}
\hline Ülke adı & 2006 & 2007 & 2008 & 2009 & 2010 & 2011 & 2012 & 2013 & 2014 & 2015 & 2016 \\
\hline Arnavutluk & 9,6 & 15,0 & 23,9 & 41,2 & 45,0 & 49,0 & 54,7 & 57,2 & 60,1 & 63,3 & 66,4 \\
\hline Ermenistan & 5,6 & 6,0 & 6,2 & 15,3 & 25,0 & 32,0 & 37,5 & 41,9 & 54,6 & 64,3 & 67,0 \\
\hline Bulgaristan & 27,1 & 33,6 & 39,7 & 45,0 & 46,2 & 48,0 & 51,9 & 53,1 & 55,5 & 56,7 & 59,8 \\
\hline Bosna Hersek & 25,1 & 27,9 & 34,7 & 37,7 & 42,8 & 43,9 & 45,1 & 48,5 & 49,9 & 52,6 & 54,7 \\
\hline Belarus & 16,2 & 19,7 & 23,0 & 27,4 & 31,8 & 39,6 & 46,9 & 54,2 & 59,0 & 67,3 & 71,1 \\
\hline Çek Cum. & 47,9 & 51,9 & 63,0 & 64,4 & 68,8 & 70,5 & 73,4 & 74,1 & 74,2 & 75,7 & 76,5 \\
\hline Estonya & 63,5 & 66,2 & 70,6 & 72,5 & 74,1 & 76,5 & 78,4 & 80,0 & 84,2 & 88,4 & 87,2 \\
\hline Gürcistan & 7,5 & 8,3 & 10,0 & 20,1 & 26,9 & 31,5 & 36,9 & 43,3 & 44,0 & 47,6 & 58,0 \\
\hline Hurvatistan & 38,0 & 41,4 & 44,2 & 50,6 & 56,6 & 57,8 & 61,9 & 66,7 & 68,6 & 69,8 & 72,7 \\
\hline Macaristan & 47,1 & 53,3 & 61,0 & 62,0 & 65,0 & 68,0 & 70,6 & 72,6 & 75,7 & 72,8 & 79,3 \\
\hline Kazakistan & 3,3 & 4,0 & 11,0 & 18,2 & 31,6 & 50,6 & 61,9 & 63,3 & 66,0 & 70,8 & 74,6 \\
\hline Kurgizistan & 12,3 & 14,0 & 15,7 & 16,0 & 16,3 & 17,5 & 19,8 & 23,0 & 28,3 & 30,2 & 34,5 \\
\hline Litvanya & 43,9 & 49,9 & 55,2 & 59,8 & 62,1 & 63,6 & 67,2 & 68,5 & 72,1 & 71,4 & 74,4 \\
\hline Letonya & 53,6 & 59,2 & 63,4 & 66,8 & 68,4 & 69,7 & 73,1 & 75,2 & 75,8 & 79,2 & 79,8 \\
\hline Moldova & 19,6 & 20,5 & 23,4 & 27,5 & 32,3 & 38,0 & 43,4 & 60,0 & 67,0 & 69,0 & 71,0 \\
\hline Karadağ & 28,9 & 30,8 & 32,9 & 35,1 & 37,5 & 35,6 & 56,8 & 60,3 & 61,0 & 68,1 & 69,9 \\
\hline Polonya & 44,6 & 48,6 & 53,1 & 59,0 & 62,3 & 61,9 & 62,3 & 62,8 & 66,6 & 68,0 & 73,3 \\
\hline Romanya & 24,7 & 28,3 & 32,4 & 36,6 & 39,9 & 40,0 & 45,9 & 49,8 & 54,1 & 55,8 & 59,5 \\
\hline Rusya & 18,0 & 24,7 & 26,8 & 29,0 & 43,0 & 49,0 & 63,8 & 68,0 & 70,5 & 73,4 & 73,1 \\
\hline Sirbistan & 27,2 & 33,2 & 35,6 & 38,1 & 40,9 & 42,2 & 48,1 & 53,5 & 62,1 & 65,3 & 67,1 \\
\hline Slovakya & 56,1 & 61,8 & 66,1 & 70,0 & 75,7 & 74,4 & 76,7 & 77,9 & 80,0 & 77,6 & 80,5 \\
\hline Slovenya & 54,0 & 56,7 & 58,0 & 64,0 & 70,0 & 67,3 & 68,3 & 72,7 & 71,6 & 73,1 & 75,5 \\
\hline Tacikistan & 3,8 & 7,2 & 8,8 & 10,1 & 11,6 & 13,0 & 14,5 & 16,0 & 17,5 & 19,0 & 20,5 \\
\hline Türkiye & 18,2 & 28,6 & 34,4 & 36,4 & 39,8 & 43,1 & 45,1 & 46,3 & 51,0 & 53,7 & 58,3 \\
\hline Ukrayna & 4,5 & 6,6 & 11,0 & 17,9 & 23,3 & 28,7 & 35,3 & 41,0 & 46,2 & 48,9 & 52,5 \\
\hline Özbekistan & 6,4 & 7,5 & 9,1 & 11,9 & 15,9 & 18,6 & 23,6 & 26,8 & 35,5 & 42,8 & 46,8 \\
\hline
\end{tabular}

Kaynak: https://data.worldbank.org 
Tablo 19 incelendiğinde 2006-2016 yılları arasında internet kullanıcılarında çok hızlı artış olduğu görülmektedir. İnternet kullanıcılarındaki en hızlı artış Kazakistan'da olmuştur. 2006 yılında internet kullanıcıları toplam nüfusun \%3,3'ünü oluştururken, 2016yılında bu oran \%74,6' ya çıkmıştır. En düşük artış oranı ise Estonya'da gerçekleşmiştir. 2006 yılında internet kullanıcıları toplam nüfusun \%63,5'ini oluştururken, 2016yılında bu oran \%87,2' ye çıkmıştır. Türkiye'deki internet kullanıcılarına bakmak istersek yine yıllar itibariyle önemli oranda artış olduğunu söyleyebiliriz. Şöyle ki, 2006 yılında internet kullanıcıları toplam nüfusun \%18,2'sini oluştururken, 2016yılında bu oran \%58,3'e çıkmıştır. İnternet kullanıcıları bakımından Türkiye yirmi ikinci sırada yer almaktadır.

\section{Sonuç}

Sanayi toplumundan bilgi toplumuna geçişin etkilerinin yoğun olarak hissedildiği günümüzde teknolojinin ve nitelikli işgücünün önemi daha iyi anlaşılmaktadır. Yeni teknolojilerin gelişmesi, ülkelerin bu gelişen teknolojilere uyum sağlama çabaları rekabet gücünü artmasında önemli rol oynamaktadır. İş gücü profilindeki iyileşmeler ve teknolojik anlamda kazanılan avantaj ekonomik büyümenin tetikleyici unsurları haline gelmiştir.

Çalışmada 2006-2016 yılları arasında Avrupa ve Orta Asya'da yer alan 26 ülke bilgi ekonomisi göstergeleri bakımından karşılaştırılmıştır. Karşılaştırmada, GSYİH, İnsani Gelişim İndeksi, Sanayi Sektöründeki İstihdam Oranı, Hizmetler Sektöründeki İstihdam Oranı, Mal ve Hizmet İhracatı, Ticaret özgürlüğü, Hükümet Etkinliği, Düzenleme Niteliği, Hukuk Kuralı, Doğumda Yaşam Beklentisi, Ortaöğretime Katılma Oranı, Yükseköğretime Katılma Oranı, Yüksek Teknoloji İhracatı, Patent Sayısı, Ar-ge Harcamaları, Ar-Ge Araştırmacıları, Bilimsel ve Teknik Makaleleri, Telefon Aboneliği ve İnternet Kullanıcıları değişkenler kullanılmıştır.

Araştırma sonucunda veriler karşılaştırıldığında; 2016 yılı itibariye en büyük büyüme $\% 7,8$ ile Özbekistan'da, en düşük büyüme -\%2,5 oranında Belarus'ta, Türkiye'de ise büyüme \%3,2 düzeyinde gerçekleşmiştir. İnsani gelişme endeksi 2015 yılında en yüksek 0,9 ile Slovenya, Çek Cumhuriyeti, Estonya ve Polonya'da gerçekleşirken en düşük -0,6 ile Tacikistan'da gerçekleşmiştir. Bu oran Türkiye'de ise 0,8'dir. 2016 yılındaki sanayi sektöründeki istihdam oranı \% 38,1 ile Çek Cumhuriyetinde en yüksek değerini almış, \%15,8 ile de Ermenistan'da en düşük değerini almıştır. Türkiye'deki sanayi sektöründeki istihdam oranı \%26,8'dir. Yine aynı yıl hizmetler sektöründeki istihdam oranı \%74,4 ile Karadağ'da en yüksek değeri \%32,7 ile Tacikistan'da en düşük değeri almıştır. Bu değişkenin Türkiye'de almış olduğu değer ise \%53,7'dir. 2016 yllindaki mal ve hizmet ihracatı \%94,6 ile Slovakya'da, \%13,3 ile Tacikistan'da gerçekleşmiştir. Türkiye de ise mal ve hizmet ihracatı \%22 oranında gerçekleşmiştir. Ticaret özgürlüğü \%88,6 ile Gürcistan'da en yüksek \%65,6 ile Özbekistan'da en düşük değeri almıştır. Türkiye'de ise bu oran \%84,4 düzeyindedir. Hükümet etkinliği 1,1 değerinde Çek Cumhuriyeti, Estonya, Litvanya ve Slovenya'da -0,9 ile Kırgızistan'da gerçekleşmiştir. Türkiye'deki değer ise 0,1'dir. Düzenleme niteliği 1,7 ile Slovakya'da en yüksek değeri ve -1,6 ile Özbekistan'da en düşük değeri almıştır. Türkiye'de ise bu değer 0,2'dir. Hukuk kuralı 1,2 ile Estonya'da -1,2 ile Tacikistan'dadır. Türkiye'de ise -0,2'dir. Doğumda yaşam beklentisi 80,8 ile en yüksek değeri Slovenya'da 71 ile en düşük değeri Kırgızistan'da almıştır. 
Türkiye'de ise doğumda yaşam beklentisi 75,8 yaş düzeyindedir. Ortaöğretime katılma oranı en yüksek değeri \%112,2 ile Letonya'da, en düşük değeri \%86 ile Ermenistan'da almıştır. Türkiye'de bu oran 75,8'dir. Yükseköğretime katılma oranı en yüksek \%95,4 ile Türkiye'de en düşük \%8,4 ile Özbekistan'da gerçekleşmiştir. İleri teknoloji ihracatı en yüksek \%30,4 ile Kazakistan'da \%0,6 ile Arnavutluk'ta gerçekleşmiştir. Türkiye'de ise ileri teknoloji ihracatının payı \%2'dir. Toplam patent sayısı en çok 41.587 adet ile Rusya'da en az 10 adet ile Karadağ'dadır. Türkiye'deki toplam patent sayısı ise 2016 yılı itibariyle 6.848'dir. Ar-Ge harcamasına ayrilan pay 2015 yılında en çok \%2,2 oranında Slovenya'da \%0,1 oranında Kırgızistan, Tacikistan ve Türkiye'dedir. 2015 yılında Ar-Ge araştırmacılarının sayısı 3.821 ile Slovenya'da en yüksek, 329 ile Bosna Hersek'te en düşük değerini almıştır. Türkiye'deki Ar-Ge araştırmacı sayısı ise 1.157'dir. 2016 yılı itibariyle bilimsel makale sayısı en çok 59.134 adet Rusya'da, en düşük değer 48 adet ile Tacikistan'dadır. Aynı yıl Türkiye'de yazılan bilimsel makale sayısı ise 33.902'dir.Telefon aboneliği ise 189 ile Karadağ'da en yüksek, 85 ile Özbekistan'da en düşük değerini almıştır. Türkiye'deki telefon aboneliği sayısı ise 108'dir. Toplam nüfus içindeki internet kullanıcıların payı \%87,2 ile en yüksek değerini Estonya'da, en düşük değerini ise \%20,5 ile Tacikistan'da almıştır. Türkiye'deki İnternet kullanıcıları oranı \%58,3’tür.

Karşılaştırma sonuçlarına göre Türkiye Bilgi ekonomisi göstergelerinde çok iyi performans sergilememektedir. Her ne kadar bilgi ekonomisi olma yolunda önemli adımlar atılmaya çalışıyor olsa da henüz istenilen aşamaya gelmediği görülmektedir. Öncelikle bilgi üreten nitelikli işgücünün önemi anlaşılmalıdır. Bunun için eğitim politikaları gözden geçirilmelidir. Ar-Ge'de istihdam alanları yaratılmalı bu alanda çalışan bireyler desteklenmedir. Bununla birlikte Ar-Ge'nin önemi anlaşılmalı ve bu alana gereken yatırımlar yapılmalıdır. Teknoloji anlamında dışa bağımlı ülke konumundan teknoloji üreten ülke konumuna geçildiğinde bilgi ekonomisinde üst seviyelerde yer alacağı açıkça görülmektedir.

Bir ülkenin hızlı büyümesinin temelinde nitelikli iş gücü ve ileri teknolojini yaratılması yatmaktadır. Eğer ki bir ülkede büyüme ve sürdürülebilir kalkınmanın devamlılığ Ar-Ge faaliyetlerine gereken önem verilmeli ve bu alanda yeterince yatırım yapılmalı, beşeri sermayenin önemi anlaşılmalı, eğitim ve sağlık alanlarına gereken yatırım yapılmalı, katma değer yaratan teknolojik ürünler üretilmeli, bu ürünler yalnızca iç pazara sunulmamalı aynı zamanda bu ürünlerin ihracatı için girişimlerde bulunulmalıdır. Genel olarak değerlendirildiğinde bilgi ekonomisinde gelişmiş ülkelerin seviyelerini yakalamaya çalışan gelişmekte olan ülkelerin yukarıda belirtilen unsurlara gereken önemi vermeleri germektedir. 


\section{Kaynakça}

Akın, H. B. (02.01.2009). Yeni Ekonomi: Kavramlar, Sorunlar ve Beklentiler http://www.bilgiyonetimi.org/cm/pages/mkl_gos.php?nt=263.

Atkinson, R. ve Court, R. (1998) "The New Economy Index" http://www.neweconomyindex.org/index_nei.html.

Auken, Howard V., Madrid - Guijarro, A., and Garcia-Perez-De-Lema D. (2008). Innovation and Performance in Spanish Manufacturing SMEs. International Journal of Entrepreneurship and Innovation Management, 8(1), s. 36-56.

Barışık, S. ve Yirmibeşçik, O. (2012). Türkiye'de yeni ekonominin oluşum sürecini hızlandırmaya yönelik uyum çabaları. Uluslararası Yönetim İktisat ve İşletme Dergisi, 2(4), 39-62.

Cecchetti S. G. (2002). The New Economy and the Challenges for Macroeconomic Policy, Working Paper Series, 8935.

Chen, D., Dahlman, C. (2005). The knowledge economy, the KAM methodology and World Bank operations. The World Bank Washington DC 20433.

Çeken, Ç. K. (2016). Türkiye'nin Bilgi Ekonomisi Performansı (2004-2014 Dönemi), Dicle Üniversitesi Hukuk Fakültesi Dergisi, 21(34), 99-139.

Davies, G., Brookes, M. and Williams N. (2000). Technology, the Internet and the New Global Economy, Goldman Sachs Global Economic Paper.

Dura, C. (2009). Yeni Dış Ticaret Teorileri: Genel Bir Bakış (I), http://www.cihandura.com/eski/index.php?option=com_content\&task=view\&id=341\&I temid $=64$.

Ersöz, F. (2009). Avrupa inovasyon göstergeleri (EIS) 1ışğında Türkiye'nin konumu, ITU Journal Series B: Social Sciences, 6(1).

Ersöz, F., Bayraktar, T. ve Ersöz, T. (2013). Dünyada ve Türkiye’de İnovasyon Göstergelerinin Analizi.https://www.researchgate.net/profile/Filiz_Ersoz2/publication/315832418_Duny ada_ve_Turkiye'de_Inovasyon_Gostergelerinin_Analizi_-_An_Analysis_of_Innovation _on_World_and_Turkey/links/58ea9193a6fdccb4a834efe4/Duenyada-ve-TuerkiyedeInovasyon-Goestergelerinin-Analizi-An-Analysis-of-Innovation-on-World-andTurkey.pdf.

Erkekoğlu, H. ve Arıç, K. H. (2013). APEC Ülkeleri ve Türkiye'nin Bilgi Toplumu Kriterleri Açısından İstatistiksel Analizi ve Bazı Tespitler. Bilgi Ekonomisi ve Yönetimi Dergisi, 8(1), 103-114.

Gelgeç, G., Hatırlı, S. A. (2018). Bilgi Ekonomisi ve Büyüme Arasindaki İlişki: Türkiye Örneği, Suleyman Demirel University Journal of Faculty of Economics \& Administrative Sciences, 23(1), 97-122.

Gordon, R. J. (2000). Does The 'New Economy' Measure up to the Great Inventions of The Past?, NBER Working Paper, 7833, 1-69. 
Gürdal, O. (2004). Bilgi Ekonomisi ve/veya Yeni Ekonomi’ nin Reddettikleri, Bilgi Dünyası, $5(1), 48-73$.

Karagül, M. (2003). Beşeri Sermayenin Ekonomik Büyümeyle İlişkisi ve Etkin Kullanımı Akdeniz İ.̇.B.F. Dergisi, 5, 79-90.

Kaynak, S. (2011). Avrupa Birliği Yolunda Bilim ve Teknoloji Bağlamında Türkiye’nin AB-27 Ülkeleri Karşısındaki Mevcut Durumu, Bilgi Ekonomisi ve Yönetimi Dergisi, VI(II), 151159.

Landefeld J. S., Fraumeni B. M. (2001). Measuring the New Economy, Survey of Current Business, 23-40.

Mahdian, M., Sehat, M., Fazel, M. R., Rahimian, H., Mohammadzadeh, M. (2016). Life expectancy at birth in Aran-Bidgol region, Iran, 2012: A study based on corrected Health Houses data, International Journal of Epidemiologic Research, 3(3), 259-267.

Meçik, O. (2013). Türkiye İçin 2010-2012 Dönemi Karşılaştırmalı Bilgi Ekonomisi Analizi, Eskişehir Osmangazi Üniversitesi İktisadi ve İdari Bilimler Dergisi, 8(2), 115-139.

Nordhaus, W. D. (2000). Technology, Economic Growth, and the New Economy, http://www.econ.yale.edu/ nordhaus/homepage/prod_grow_new_econ_112000.pdf.

Odabaşı, Y., Erdal, E. (2018). Bilgi Ekonomisi ve Ekonomik Büyüme: Seçilmiş OECD Ülkeleri Üzerine Bir İnceleme, Avrasya Sosyal ve Ekonomi Araştırmaları Dergisi, 5(12), 439-459.

Özer, M., Çiftçi, N. (2009). Ar-Ge Harcamaları ve İhracat İlişkisi: OECD Ülkeleri Panel Veri Analizi, Dumlupınar Üniversitesi Sosyal Bilimler Dergisi, 23, 39-49.

Özkan, G. ve Alancioğlu, S. (2017). Bilgi Ekonomisi İndeksi Performans Göstergelerinin Türkiye Açısından Ar-Ge Harcamaları Analizi, ASSAM Uluslararası Hakemli Dergi, 4(8), $1-12$.

Özsağır, A. (2007). Bilgi Ekonomisi, İstanbul: Nobel.

Salvatore, D. (2003). The New Economy and growth in the G-7 countries, Journal of Policy Modeling, 25, 531-540.

Salur, S. (2016). Kam Metodolojisi ve Türkiye'nin Bilgi Ekonomisindeki Yeri, Akademik Sosyal Araştırmalar Dergisi, 4(28), 167-184.

Salur, S., Vurgun, Ş., Gülcan, Z. (2016). Bilgi Ekonomisinin Türkiye Ve Ab Ülkeleri Açısından Değerlendirilmesi (2000-2013), Journal of International Social Research, 9(43). 20982112.

Seyfullahoğulları, A., Akbaş, M. E. (2013). Ekonomide Bilgi İletişim Teknolojilerinin Önemi: Ülkeler Bazında Karşılaştırmalı Bir Analiz, Öneri Dergisi, 10(40), 201-212.

Stiroh, K, J. (2001). New and Old Economics in the 'New Economy, http://www.j-bradforddelong.net/Econ_Articles/macro_annual/Stiroh/ks_new2.pdf. 
Şanlısoy, S. (2015). Türk Cumhuriyetlerinin Bilgi Ekonomisi Analizi, Optimum Ekonomi ve Yönetim Bilimleri Dergisi, 2(2), 101-122.

Teker D., Teker S., Sönmez M. (2012). Ekonomik Değişkenlerin Kadın ve Erkeğin Yaşam Süresine Etkisi, İşletme Araştırmaları Dergisi 4(3), 118-126.

Triplett, J. E. (1999). The Solow productivity paradox: what do computers do to productivity?, Canadian Journal of Economics, 32(2).

Türedi, S. (2013). Bilgi ve İletişim Teknolojilerinin Ekonomik Büyümeye Etkisi: Gelişmiş ve Gelişmekte Olan Ülkeler İçin Panel Veri Analizi. Gümüshane Üniversitesi Sosyal Bilimler Enstitüsü Elektronik Dergisi, 4(7), 298-322.

Ünal, T. ve Seçilmiş, N. (2013). Ar-Ge Göstergeleri Açısından Türkiye ve Gelişmiş Ülkelerle Kıyaslaması, İşletme ve İktisat Çalışmaları Dergisi, 1(1), 12-25.

Uğur, B. ve Şahin M. (05.03.2009) Yeni Ekonominin Mikro ve Makro Ekonomi Üzerine Etkileri, http://www.bilgiyonetimi.org/cm/pages/mkl_gos.php?nt=270 